Article

\title{
Genetic and Genomic Diversity in a Tarwi (Lupinus mutabilis Sweet) Germplasm Collection and Adaptability to Mediterranean Climate Conditions
}

\author{
Norberto Guilengue ${ }^{1}$, Sofia Alves ${ }^{1}$, Pedro Talhinhas ${ }^{1,2, *}$ and João Neves-Martins ${ }^{1}$ \\ 1 Instituto Superior de Agronomia, Universidade de Lisboa, 1349-017 Lisbon, Portugal; \\ guilenguen@gmail.com (N.G.); sofiaalves@isa.ulisboa.pt (S.A.); nevesmartins@isa.ulisboa.pt (J.N.-M.) \\ 2 LEAF, Linking Landscape, Environment, Agriculture and Food, Instituto Superior de Agronomia, \\ Universidade de Lisboa, 1349-017 Lisbon, Portugal \\ * Correspondence: ptalhinhas@isa.ulisboa.pt; Tel.: +351-2-1365-3249
}

Received: 7 October 2019; Accepted: 20 December 2019; Published: 22 December 2019

\begin{abstract}
Lupinus mutabilis (tarwi) is a species of Andean origin with high protein and oil content and regarded as a potential crop in Europe. The success in the introduction of this crop depends in part on in depth knowledge of the intra-specific genetic variability of the collections, enabling the establishment of breeding and conservation programs. In this study, we used morphological traits, Inter-Simple Sequence Repeat markers and genome size to assess genetic and genomic diversity of 23 tarwi accessions under Mediterranean conditions. Phenotypic analyses and yield component studies point out accession LM268 as that achieving the highest seed production, producing large seeds and efficiently using primary branches as an important component of total yield, similar to the L. albus cultivars used as controls. By contrast, accession JKI-L295 presents high yield concentrated on the main stem, suggesting a semi-determinate development pattern. Genetic and genomic analyses revealed important levels of diversity, however not relatable to phenotypic diversity, reflecting the recent domestication of this crop. This is the first study of genome size diversity within L. mutabilis, revealing an average size of $2.05 \mathrm{pg} / 2 \mathrm{C}$ (2001 Mbp) with 9.2\% variation (1897-2003 Mbp), prompting further studies for the exploitation of this diversity.
\end{abstract}

Keywords: Lupinus mutabilis; genetic diversity; morphological traits; ISSR; genome size; Mediterranean climate

\section{Introduction}

The genus Lupinus includes more than 280 species [1], approximately $90 \%$ of which are native and widely distributed throughout the American continent [2,3], with greater inter- and intra-specific genetic variability than in Euro-African species. Lupinus mutabilis Sweet (also known as tarwi, chocho, altramuz and Andean lupin) is native from the Andean region in South America. The species is autoand allogamic with wide variability of flower, stem and seed colours, and exhibits indeterminate growth $[4,5]$. It has been domesticated in the Andean region and used for grain production, forage, green manure, fixing atmospheric nitrogen and soil conservation $[4,6]$. In spite of their high alkaloid content $[7,8]$, tarwi seeds have high nutritional value, containing up to $53 \%$ protein and $24 \%$ lipids [9]. The nutritional attributes found in tarwi are supposedly better than those in soybeans [10] and for this reason it is called Andean soybean [11]. Tarwi protein is rich in globulins ( $43 \%-45 \%)$ and albumins $(8 \%-9 \%)$ and the oil has high quality and does not require industrial removal of the linolenic acid like in soybean [12,13]. Additionally, low alkaloid $(<0.1 \%)$ lines have been selected in L. mutabilis [14].

Tarwi exhibits key traits of domestication, including indehiscent pods and seeds with permeable tegument, representing a locally important crop in several Andean areas [15]. Recently the species 
L. piurensis was considered the wild relative from which tarwi would have evolved until arriving at the domesticated form known nowadays [16]. According to this hypothesis, no wild specimens of L. mutabilis exist and the species would have suffered a classic domestication bottleneck no later than 2600 years before present time [16], leading to a recognizably low genetic diversity of tarwi [17]. Nevertheless, the crop conceals important morphological variability, which is related to the high variability of agroecological conditions across its native range [18]. For instance, small plants occur in the Potosi region, where the altitude exceeds $3500 \mathrm{~m}$ and of low temperatures and precipitation prevail. Branched and tall plants are found in the Andean valleys of Bolivia and Southern Peru with more than $50 \%$ of their production centred on the main stem. Highly branched plants with over $1.8 \mathrm{~m}$ in height, with long vegetative period and little production in the main stem occur in Colombia, Ecuador and northern Peru, under frost-free climates [18].

Due to its high plasticity, tarwi has a wide adaptation to varied soils, precipitation and temperature regimes [6]. In the light of this broad adaptation, attempts have been made in order to introduce tarwi to European conditions [12] to reduce local dependence on imported soybeans. As such, seeds harvested in the Andean region have been used during several years to select plants with determined growth in the Mediterranean conditions. As a result, a germplasm collection was created focused on promising accessions. The success in introducing this species in this region will depend in part on the deep knowledge of the genetic variability of this collection. Thus, understanding the genetic variability is extremely important for the establishment of future breeding and conservation programmes [19].

Research on crop genetic variability has been based on morphological descriptors and molecular markers as the main tools [20-23]. The morphological descriptors are used to generate relevant information about the description and classification of the germplasm collections in order to allow efficient use in breeding programmes $[24,25]$. Morphological analysis and molecular markers can be used together to generate more reliable and consistent information. Contrary to morphological descriptors, molecular markers have the advantage to not depend on the environment, phenotype and stage of development of the plant [26]. Several DNA markers are available and can be used in genetic diversity studies, among which are Inter-Simple Sequence Repeat (ISSR) markers. ISSR markers allow preliminary screening of germplasm collections and have been used to perform genetic mapping, phylogenetic and evolutionary studies because of their good repeatability, high polymorphism, easy handling and low cost [27-30]. ISSR analyses thus enable the selection of contrasting accessions that, together with pertaining morphological traits, can be selected for further characterisation using more informative markers, such as Simple Sequence Repeats. In addition to the use of molecular markers, in recent years the use of nuclear DNA content information to explain intra-specific genetic diversity has been increasing [31-33]. The DNA content is important for understanding molecular, cellular and evolutionary genomic mechanisms [34]. Flow cytometry is widely used for DNA content estimation due to its simplicity and efficacy [35]. This technique has been applied successfully in the estimation of nuclear DNA content in different species. In particular, flow cytometry was employed to differentiate Lupinus species based on the genome size [36]. However, there are few studies addressing intraspecific variability in L. mutabilis based on morphological traits, ISSR $[37,38]$ and on DNA content. This prompts a need to characterise L. mutabilis germplasm collections in depth, both under genotypic and phenotypic perspectives. Instituto Superior de Agronomia (ISA), Portugal, has one of the most important collections of Lupinus in the world, containing over 1300 Lupinus accessions, including L. mutabilis. However, little is known about the genetic variability in this collection. The present study aims to evaluate genetic and genomic diversity in 23 L. mutabilis accessions present in ISA collection using 37 morphological traits, six ISSR markers and genome size data, contributing simultaneously to assess its adaptability to Mediterranean climate conditions and to provide genotypic data. 


\section{Materials and Methods}

\subsection{Plant Materials}

A total of 23 L. mutabilis accessions were selected from the ISA Lupinus germplasm including five accessions provided by the Julius Kühn-Institut (JKI), Germany (e.g., Table 2). Lupinus albus cultivars Misak and Mihai were used as reference in the morphological characterization because of their high adaptation to the Mediterranean conditions and as outgroups/standards in the ISSR marker and genome size analyses.

\subsection{Morphological Analysis}

Field experiments were conducted at Tapada de Ajuda in Lisbon (coordin: 38.709133, -9.182976, alt: $60 \mathrm{~m}$ ) on a vertisol in the 2016/17 (sowing date: 29 December) and 2017/18 (sowing date: 18 December) seasons under rain-fed conditions. Meteorological data were collected daily from the weather station located adjacent to the field. Soil water balances were calculated according to Allen et al. [39].

The experimental design adopted was randomized block with three replicates. Each replicate was composed of $261.8 \mathrm{~m}^{2}$-plots with 20 plants in each plot (immediately surrounded by a $60 \mathrm{~cm}$-wide edge of L. albus 'Misak' plants to avoid border effects) and the total number of plots in the assay was 78. For morphological characterization, 10 plants of each plot were selected as recommended by Talhinhas et al. [40].

Data of morphological characterization were obtained based on Lupinus spp. descriptors [41], as listed in Table 1. Yield components and vegetative traits were analysed considering a two-factor experimental design (genotype and year), with differences being statistically analysed using the Kruskal Wallis test. Characteristics for multivariate analysis were selected based on correlation coefficients and heritability values [40]. Variables with correlation above 0.85 were considered redundant and thus one of them was excluded. Meanwhile, variables with low heritability $(<65 \%)$ were also excluded, as these were explained by environmental factors.

Univariate analysis (UA) was performed to compare each individual characteristic across the accessions. Before running the UA, normality and homogeneity of variances was tested. Since data did not follow normal distribution and the variance was not homogeneous, an analysis of variance (ANOVA) based on rank transformation for non-parametric analysis was performed [42]. Post-hoc Tukey's honest significant difference (HSD) test of means was performed for all variables at $5 \%$ significance. Afterwards, broad sense heritability $\left(\mathrm{H}^{2}\right)$, genotypic variance $\left(\sigma^{2} \mathrm{~g}\right)$, phenotypic variance $\left(\sigma^{2} \mathrm{P}\right)$, phenotypic coefficient of variance $(\mathrm{PCV})$ and genotypic coefficient of variance $(\mathrm{GCV})$ were estimated to understand the genetic variation between accessions and environment, as well as the genetic effects on different traits, following Mazid et al. [43].

Multivariate analysis was performed for all 25 accessions and all characteristics selected and represented in a single graphic, as described by Talhinhas et al. [40]. Standardized morphological data transformation (mean $=0$, and standard deviation $=1$ ) was performed before conducting multivariate analysis. Cluster analysis was performed based on Euclidean distance and average method for the 25 accessions. A dendrogram was constructed using an unweighted pair group method of arithmetic mean (UPGMA) algorithm. Principal component analysis (PCA) was performed and eigenvectors and eigenvalues were projected to visualize the components. All analyses were performed in the RStudio program version 1.1.456 (The R consortium, Boston, USA). 
Table 1. List of morphological traits evaluated in the experiment, method and unit of measurement.

\begin{tabular}{|c|c|c|}
\hline Acronym & Trait $^{1}$ & Method (unit) \\
\hline DUF & Days from sowing until flowering ${ }^{3}$ & Counting $\left(\mathrm{nr}^{4}\right)$ \\
\hline NLMS & Number of leaves on the main stem & Counting $(\mathrm{nr})$ \\
\hline HUFF & Height up to first flower & Metric meas. ${ }^{5}(\mathrm{~cm})$ \\
\hline ADNL & Average distance between leaves & $=$ HUFF/NLMS $(\mathrm{cm})$ \\
\hline NPMS & Number of pods on the main stem & Counting \\
\hline PLMS & Pod length on the main stem & Metric meas. (cm) \\
\hline PWMS & Pod width on the main stem & Metric meas. $(\mathrm{cm})$ \\
\hline RBLWPMS & Ratio length-width of pods on the main stem & $=$ PLMS $/$ PWMS $\left(\right.$ dim. $\left.^{6}\right)$ \\
\hline NSMS & Number of seeds on the main stem & Counting $(\mathrm{nr})$ \\
\hline SLMS & Seed length on the main stem ${ }^{2}$ & Metric meas. (cm) \\
\hline SWMS & Seed width on the main stem & Metric meas. (cm) \\
\hline RBLWSMS & Ratio length-width of seed on the main stem ${ }^{2,3}$ & $=\mathrm{SLMS} / \mathrm{SWMS}$ (dim.) \\
\hline NSPMS & Number of seed per pod on the main stem & Counting (nr) \\
\hline WSMS & Weight of seeds on the main stem & Weighting $(\mathrm{g})$ \\
\hline TSWMS & Thousand seeds weight on the main stem ${ }^{2}$ & $=$ WSMS $/ \mathrm{NSMS}^{*} 1000(\mathrm{~g})$ \\
\hline NPB & Number of primary branches & Counting $(\mathrm{nr})$ \\
\hline ADBPB & Average distance between primary branches 2,3 & $=\mathrm{HUFF} / \mathrm{NPB}(\mathrm{cm})$ \\
\hline SLPB & Sum of the length of primary branches & Metric meas. $(\mathrm{cm})$ \\
\hline ALPB & Average length of primary branches & $=\mathrm{SLPB} / \mathrm{NPB}(\mathrm{cm})$ \\
\hline PBL & Proportion of leaves with branches 2,3 & $=\mathrm{NPB} / \mathrm{NLMS}(\%)$ \\
\hline NPPB & Number of pods on primary branches ${ }^{2}$ & Counting (nr) \\
\hline NSPB & Number of seeds on primary branches ${ }^{2}$ & Counting (nr) \\
\hline NSPPB & Number of seeds per pod on primary branches & $=\mathrm{NSPB} / \mathrm{NPPB}(\mathrm{nr})$ \\
\hline NPPPB & Number of pods per primary branch & $=\mathrm{NPPB} / \mathrm{NPB}(\mathrm{nr})$ \\
\hline WSPB & Weight of seeds on primary branches ${ }^{2}$ & Weighting $(\mathrm{g})$ \\
\hline WSPPB & Thousand seeds weight per primary branches & Weighting $(\mathrm{g})$ \\
\hline TSWPB & Thousand seeds weight on primary branches & $=\mathrm{WSPB} / \mathrm{NSPB} \times 1000(\mathrm{~g})$ \\
\hline TBL & Total branch length & $=\mathrm{SLPB}+\mathrm{HUFF}$ \\
\hline TNP & Total number of pods ${ }^{2}$ & Counting $(n r)$ \\
\hline TNS & Total number of seeds & Counting (nr) \\
\hline TNSPP & Total number of seeds per pod & $=\mathrm{TNS} / \mathrm{TNP}(\mathrm{nr})$ \\
\hline TW & Total seed weight & Weighing (g) \\
\hline PSMS & Percentage of seed weight on the main stem & $=$ WSMS/TW $(\%)$ \\
\hline PSPB & Percentage of seed weight on primary branches ${ }^{3}$ & $=\mathrm{WSPB} / \mathrm{TW}(\%)$ \\
\hline TTSW & Total thousand seeds weight & $=\mathrm{TW} / \mathrm{TNS} \times 1000(\mathrm{~g})$ \\
\hline SWBLR & Seed weight/total branch length ratio & $=\mathrm{TW} / \mathrm{TBL} \times 100(\mathrm{~g} / \mathrm{m})$ \\
\hline
\end{tabular}

${ }^{1}$ Characteristics related with secondary and tertiary branches were excluded due to insufficiency of data; ${ }^{2}$ Redundant or non-independent characteristics excluded of multivariate analysis based on the correlation coefficient $(r>0.85)$; ${ }^{3}$ Characteristics excluded of multivariate analysis due to presenting low value of heritability $(<0.65) ;{ }^{4}$ number;

${ }^{5}$ Metric measurement; ${ }^{6}$ dim.- dimensionless.

\subsection{Molecular Analysis}

Young but fully expanded leaves of the 23 L. mutabilis accessions and of the two L. albus reference cultivars were collected and immediately frozen in liquid nitrogen and stored at $-80^{\circ} \mathrm{C}$. Freeze-dried vegetal material was used for DNA extraction using the DNeasy ${ }^{\circledR}$ Plant mini kit (Qiagen, Hilden, Germany) according to the manufacturer instructions. The DNA quality and quantity were estimated using spectrophotometry in the Gen 5 program, and electrophoresis using a 1\% agarose gel. The stock solution of DNA was diluted with sterilized water to make a working solution with a concentration of $10 \mathrm{ng} / \mu \mathrm{L}$ to be used in amplifications.

For molecular characterization, six ISSR primers were selected (Table 6) from those reported by Talhinhas et al. [44] based on preliminary analyses of a limited set of accessions. The Polymerase Chain Reaction (PCR) amplification for all primers was carried out under the following conditions: pre-denaturation $4 \mathrm{~min}$ at $94{ }^{\circ} \mathrm{C}, 40$ cycles of $30 \mathrm{~s}$ at $94{ }^{\circ} \mathrm{C}, 45 \mathrm{~s}$ at $52{ }^{\circ} \mathrm{C}$ and $2 \mathrm{~min}$ at $72{ }^{\circ} \mathrm{C}$, and a final extension at $72{ }^{\circ} \mathrm{C}$ for $10 \mathrm{~min}$. The PCR reactions were performed in a final volume of $10 \mu \mathrm{L}$ 
containing $20 \mathrm{ng}$ of DNA, $0.5 \mu \mathrm{M}$ of primer and $5 \mu \mathrm{L}$ of dNTP + Taq DNA polymerase (NZYTaq II DNA polymerase, NZYTech, Lisbon, Portugal). After amplification, products were separated by electrophoresis in a $2 \%$ agarose gel stained using GreenSafe Premium (NZYTech).

The ISSR bands were scored in a binary matrix as presence (1) or absence (0) for each accession and for each fragment size. Based on the binary matrix, parameters such as percentage of polymorphic and monomorphic bands were determined and discriminatory power of primers was calculated based on the polymorphic information content (PIC), effective multiplex ratio (EMR), resolving power (RP) and marker index (MI). PIC value is the probability for detecting polymorphism by a primer or primers combination between two randomly drawn genotypes and can be calculated using the formula $P I C=1-\Sigma p i^{2}$, where pi is the frequency of occurrence of polymorphic bands in different primers [45]. The effective multiplex ratio was calculated using the formula $E M R=n p \beta$; where $B$ is the fraction of polymorphic markers and is estimated after considering the number of polymorphic loci (np) and non-polymorphic loci (nnp) as $B=n p /(n p+n n p)$ [46]. Marker index (MI) is the primer capacity to detect polymorphic loci among different genotypes and was calculated as EMRXPIC. Resolving power $(\mathrm{RP})$ is the ability of primers to distinguish between genotypes and was calculated as $R P=\Sigma I b$, where $\mathrm{Ib}$ is the informative fragments and can take values of: $1-[2|0.5-p|] ; p$ is the proportion of total genotypes containing the band [47]. Genetic similarity was obtained according to the Jaccard similarity index. The results were used for the construction of ISSR and morphological traits dendrograms, in order to evaluate the similarity relations between the genotypes. Dendrograms were constructed based on UPGMA grouping and the ISSR results were correlated with morphological traits.

\subsection{Flow Cytometry}

For each accession, young leaves in healthy conditions were randomly collected and immediately analysed in the laboratory. Nuclear DNA content was measured by flow cytometry. Solanum lycopersicum 'Stupické' (2C $=1.96 \mathrm{pg}$; [48]) was tested as DNA standard but its genome size showed to be too close to that of L. mutabilis. Therefore, we tested L. albus as DNA standard $(2 C=1.20 \mathrm{pg}$; [49]) and for such $L$. albus 'Misak' was validated as standard by comparison to S. lycopersicum 'Stupické' and Raphanus sativus 'Saxa' (2C = $1.11 \mathrm{pg}$; [48]). Each L. mutabilis accession, together with the standard, was chopped with a razor blade in the presence of $1 \mathrm{~mL}$ of buffer (Woody Plant Buffer; [50]). The nuclear suspension obtained was then separated from plant debris using a $30 \mu \mathrm{m}$ nylon filter. After filtration, $50 \mu \mathrm{g} / \mathrm{mL}$ of propidium iodide (PI; Sigma-Aldrich) were added to stain DNA and $50 \mu \mathrm{g} / \mathrm{mL}$ of RNase (Sigma-Aldrich) ware added to prevent staining of double stranded RNA. The samples were maintaining at room temperature and analyzed using a CyFlow Space flow cytometer (Sysmex, Norderstedt, Germany) equipped with a $30 \mathrm{~mW}$ green solid-state laser emitting at $532 \mathrm{~nm}$ for optimal PI excitation. The reproducibility of results were assessed using five independent replicates for each accession. FloMax software v2.4d (Sysmex) was used to measure nuclear DNA content and three graphics were generated from data measurement: fluorescence pulse integral in linear scale (FL); fluorescence pulse integral in linear scale versus time; and fluorescence pulse integral in linear scale versus side light scatter in logarithmic scale (SSC). The absolute DNA amount of a sample was calculated based on the values of the G1 peak means, as suggested by Doležel and Bartoš [51]:

$$
\text { Sample 2C DNA content }=\frac{\text { Sample G1 peak mean }}{\text { standard G1 peak mean }} \times \text { Standard 2C DNA Content }
$$

The results generated from $2 \mathrm{C}$ DNA (in picogram) were transformed to million base pairs using the following conversion: $1 \mathrm{pg}=978 \mathrm{Mbp}$ [52]. Coefficient of variation (CV, \%) of G1 peaks in the FL histograms, and estimates of the CV of the genome size of each accession were used to assess the reliability of the results. Intra-specific genome size comparison was carried out using Kruskal Wallis test $(\alpha=0.05)$ because genome size data did not exhibit normal distribution. Data analysis was done in RStudio Program Version 1.1.456. 


\section{Results}

\subsection{Morphological Characterization and Genetic Parameters among Accessions}

Studies on the genetic variability are important because they generate relevant data for breeding programmes and can be used as basis for development and selection of superior genotypes. Here, we used morphological characterization and genetic parameters to evaluate the variability of a L. mutabilis germplasm collection under Mediterranean conditions.

Meteorological conditions during the trial were typical of the Mediterranean climate (Figure S1), although rainfall was well below average during autumn and winter and above average during spring in 2017/18, while rain was scarce in April 2016. Two-way ANOVA based on rank transformation was performed and revealed that all morphological traits exhibited significant difference at $p$-value $<0.05$. Tables 2 and 3 show the mean values, homogeneous groups and $p$ value obtained in a two-factor experimental design for morphological and reproductive characteristics, respectively. Differences analysis results for morphological traits of each year are given in Supplementary Material (Table S1). The statistical analysis of the results depict those genotypes showing differences that were consistent over the two years.

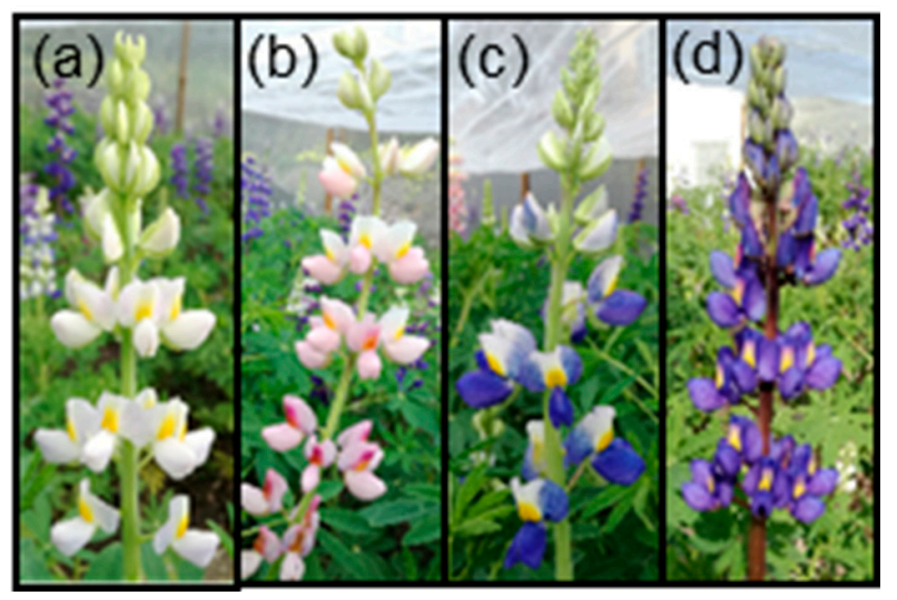

Figure 1. Lupinus mutabilis flowers and stem colours: (a) green stem, white wings, white standard with yellow central spot; (b) green stem, pale pink wings (more intense as flower matures), pale pink standard with yellow central spot (central spot turning dark pink as the flower matures); (c) green stem, blue wings, standard blue in the marginal area, white in the intermediate and yellow in the central spot; (d) purple stem, purple wings, purple standard with yellow central spot.

The results presented in Table 2 reveal that the average number of days from sowing to flowering (DUF) ranged between 80.8 (accession JKI-L309) and 103.4 (accession XM1-39) for L. mutabilis, spanning 23 days, while for L. albus cultivars the average was 98.1 days. The number of leaves on the main stem (NLMS) ranged between 12.8 and 18.0, while the number of primary branches (NPB) ranged from 2.6 to 4.6. The average numbers of leaves (NLMS) and branches (NPB) were 15.9 and 3.4, respectively, showing similar values to L. albus. On average, $21 \%$ of main stem leaves axillae harboured primary branches (PBL), with a minimum of $16 \%$ for accession JKI-L295 and a maximum of $26 \%$ for accession LM231. The average height (HUFF) of L. mutabilis plants was $55.7 \mathrm{~cm}$, ranging between $40.0 \mathrm{~cm}$ (JKI-L309) and $68.9 \mathrm{~cm}$ (Inti), while the average for L. albus cultivars was $40.4 \mathrm{~cm}$. In both experiments the accession JKI-L309 grew less than other accessions. The total length of primary branches (SLPB) varied between $81.9 \mathrm{~cm}$ for accession JKI-L309 and $163.1 \mathrm{~cm}$ for accession LM231, with an average of $122.8 \mathrm{~cm}$. The total stem length (main stem and primary branches, TBL) attained a global average of $179.4 \mathrm{~cm}$ (164.7 for L. albus), varying between $122.0 \mathrm{~cm}$ (accession JKI-L309) and 229.4 cm (LM231). The JKI-L309 accession presented low values for TBL, suggesting that this may be a semi-determinate 
genotype. Stem and flower colors varied among accessions, with no clear correlation to morphologic traits. Figure 1 depicts the four groups of flower and stem colors.

Table 2. Average values (and homogeneous groups ${ }^{1}$ ) for vegetative traits of 23 Lupinus mutabilis accessions and two L. albus cultivars ('Mihai' and 'Misak'), obtained upon analysis of variance (ANOVA) based on rank transformation.

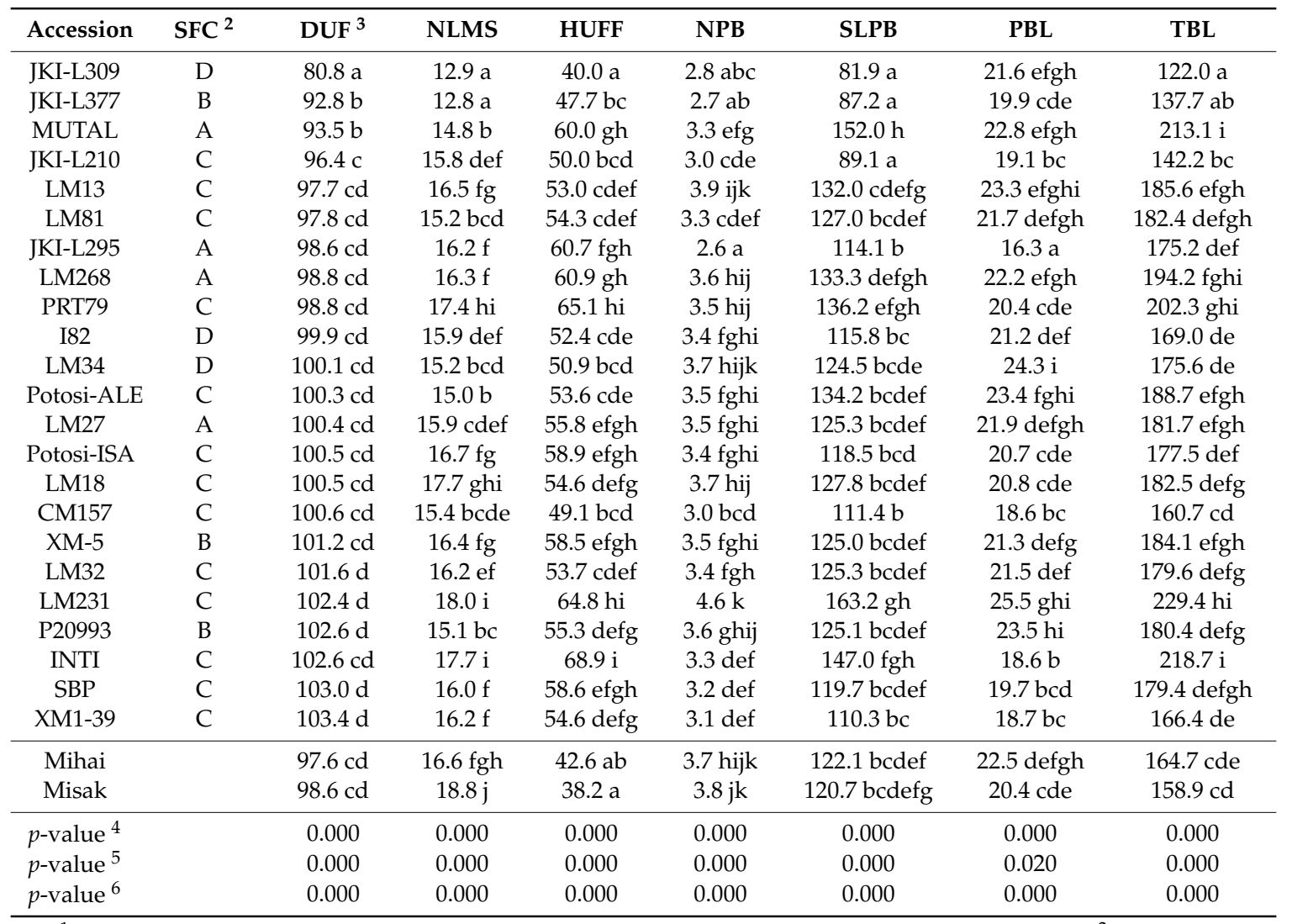

${ }^{1}$ Homogeneous groups-accessions sharing the same letter for each trait are not statistically different; ${ }^{2}$ SFC—-stem and flower colour, according to Figure $1 ;{ }^{3}$ Full name of acronyms and description of the respective morphologic traits are given in Table $1 ;{ }^{4} p$-value taking into account the accessions; ${ }^{5} p$-value taking into account the experiments; ${ }^{6} p$-value taking into account the interaction between accessions and experiments.

The total seed weight (TW) per plant (Table 3) varied 3.7×, ranging between $3.7 \mathrm{~g}$ per plant (accession JKI-L210) and $13.8 \mathrm{~g}$ per plant (accession LM268), the latter attaining a projected productivity estimated at $1533 \mathrm{~kg} / \mathrm{ha}$, although less than half of the total yield of the L. albus accessions. Dissecting yield components evidences additional variability among the accessions (Table 3 ). The total number of pods (TNP) per plant varied nearly $2.1 \times$, with a maximum of 25 pods per plant for accession Potosi-ISA. The total number of seeds (TNS) reached a maximum of 67.9 seeds per plant (accession LM34). The average number of seeds per pod (TNSPP) is 2.7, ranging between 2.2 (accession LM268) and 3.3 (accession JKI-L210). The total thousand seeds weight (TTSW) attained a global average of $187.0 \mathrm{~g}$, varying $2.85 \times$ between $101.4 \mathrm{~g}$ (accession JKI-L210) and $289.2 \mathrm{~g}$ (accession LM268). LM268 was the only L. mutabilis accession producing more yield on the primary branches than on the main stem $(40 \%$ and $60 \%$ of total yield on the main stem and on primary branches, respectively), following a similar pattern to that of L. albus cultivars. The accessions JKI-L295 and JKI-L210 produced about $80 \%$ of seed weight on the main stem. Unlike accession LM268, several L. mutabilis accessions reached superior seed yields (over $10 \mathrm{~g}$ per plant) while concentrating over $60 \%$ of their yield on the main stem: CM157, I82 and LM27. For the comparison of seed yield and vegetative development (Table 3), the seed weight/total branch length ratio (SWBLR) was calculated. SWBLR average was $2.0 \mathrm{~g}$ of seeds per 
meter of branch length in L. mutabilis $(23.1 \mathrm{~g} / \mathrm{m}$ in L. albus), ranging between $1.1 \mathrm{~g} / \mathrm{m}$ (accession LM32) and $3.3 \mathrm{~g} / \mathrm{m}$ (accession Mutal).

Table 3. Average values (and homogeneous groups ${ }^{1}$ ) for yield components of 23 Lupinus mutabilis accessions and two L. albus cultivars ('Mihai' and 'Misak'), obtained upon ANOVA based on rank transformation.

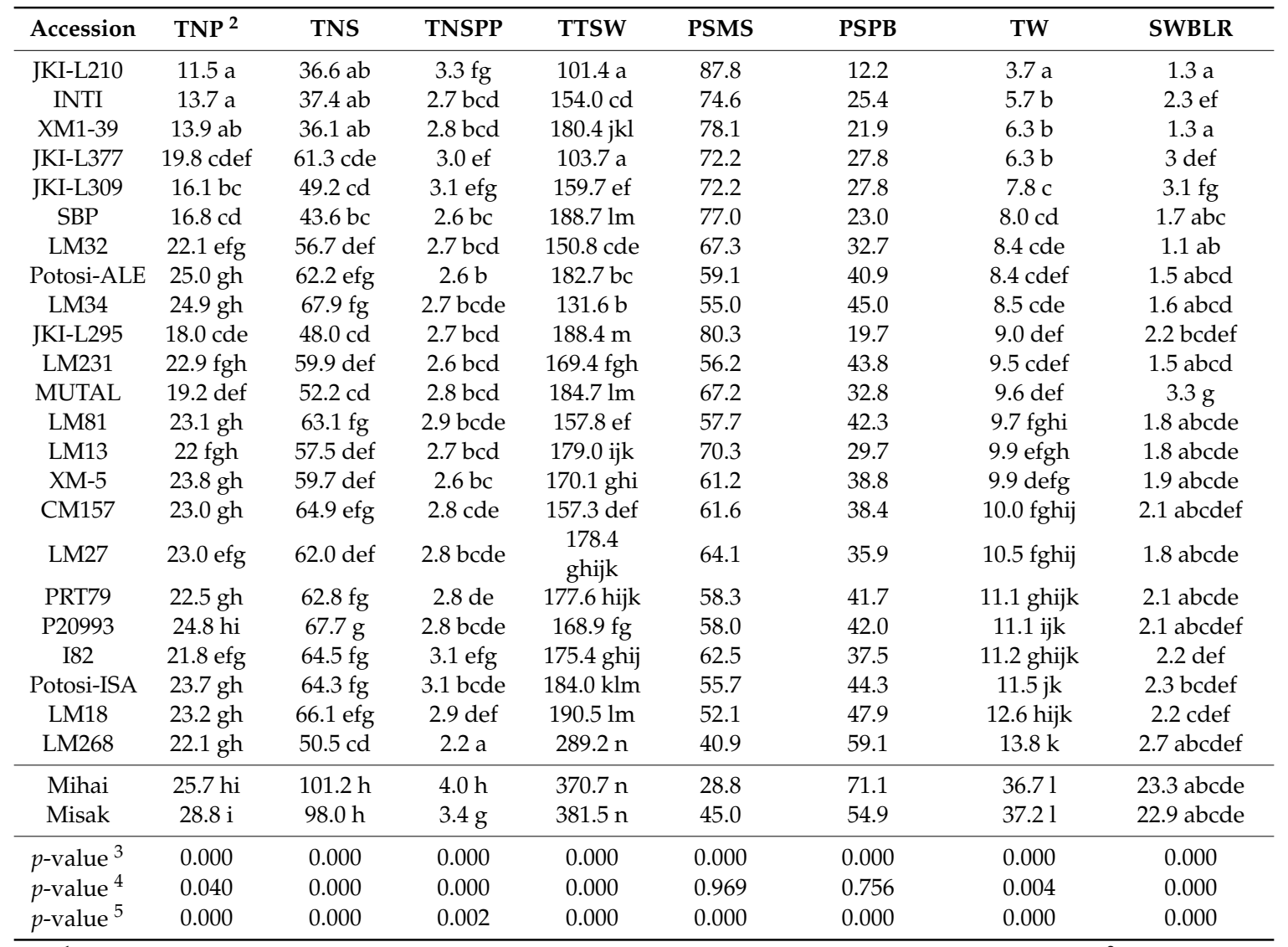

${ }^{1}$ Homogeneous groups-accessions sharing the same letter for each trait are not statistically different; ${ }^{2}$ Full name of acronyms and description of the respective morphologic traits are given in Table $1 ;{ }^{3} p$-value taking into account the accessions; ${ }^{4} p$-value taking into account the experiments; ${ }^{5} p$-value taking into account the interaction between accessions and experiments.

In Table 4 are presented the average, phenotypic and genotypic variance with their respective coefficient of variation and heritability for the 2016/17 and 2017/18 experiments. Higher values of phenotypic and genotypic variances were observed for TSWPB, TSWMS, TBL, TNS, SLPB, NSPB and WSPPB (see Table 1 for definitions). Conversely, low values were observed for ADNL, RBWLPMS, RBWLSMS, NSPMS, NPB, TNSPP, PSMS, PBL, PSPB, PWMS and SLMS. The highest phenotypic and genotypic coefficients of variation were obtained in 2017/18 for NPPB (33.64\% and $29.18 \%$ ) and NSPB (37.68\% and $30.89 \%$ ), while low values were observed in both years for DUF, RBLWSMS and RBLWPMS. In general, values of the phenotypic coefficient of variation were relatively higher than genotypic. For all characteristics, heritability ranged from $0 \%$ to $100 \%$. Most of the characteristics exhibited high heritability, while lower and medium values were found for NSPMS (0), RBWLSMS (0.53), RBWLPMS $(0.64,0.45)$, NSPPB $(0.42,0.39)$, TNSPP (0.52), DUF (0.49), SWMS (0.57), PSPB and PBL (0.63). These characteristics exhibiting low and medium values of heritability were excluded for the multivariate analysis. 
Table 4. Genetic parameters estimated for 38 quantitative traits among 23 Lupinus mutabilis accessions.

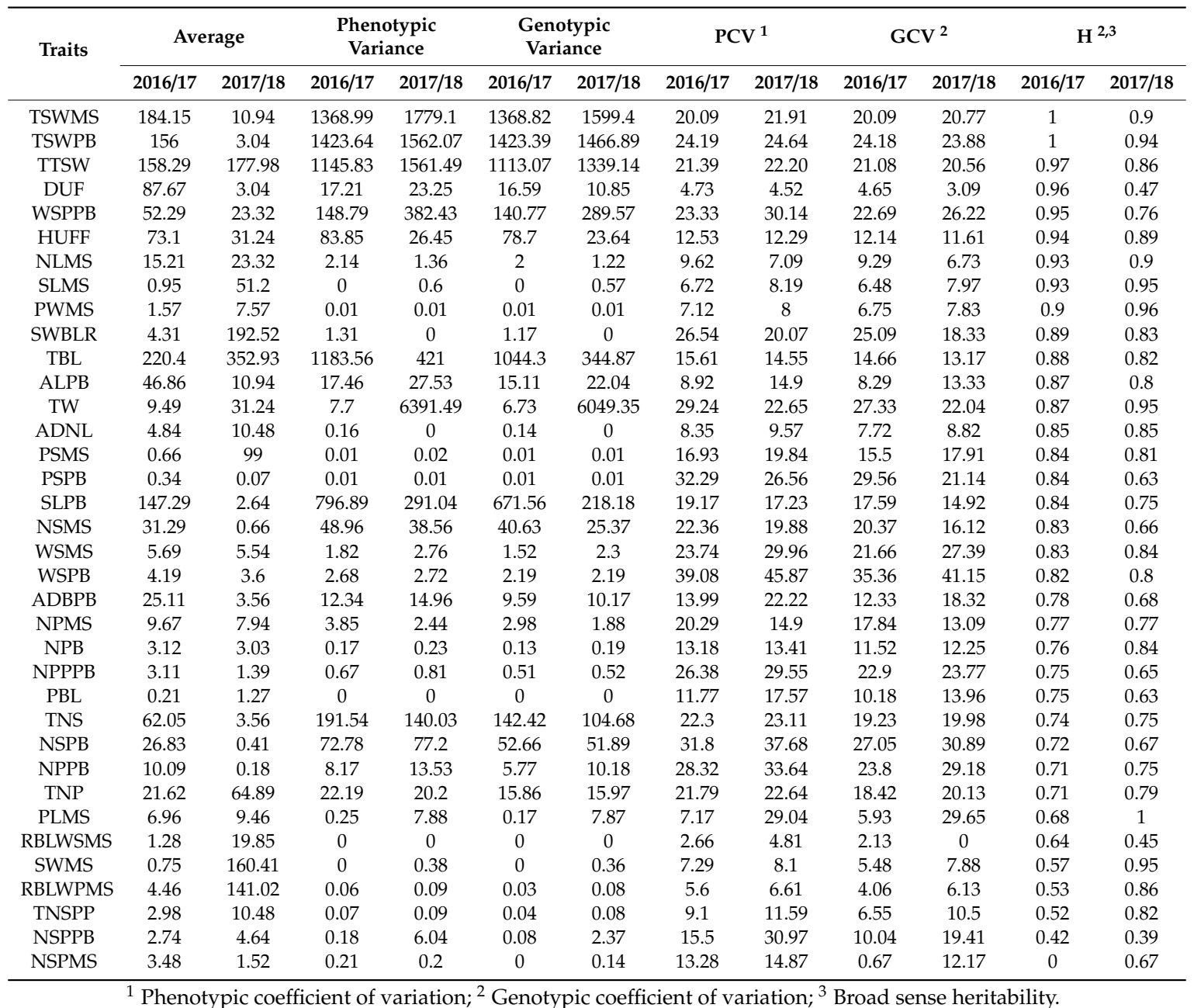

Correlation is an important test and is used to assess relationship and associations between variables and is frequently applied in several studies. The results generated after correlation coefficient analysis using the Spearman method for morphological traits in experiments of 2016/17 and 2017/18 are presented in Tables S2-1 and S2-2. Results show positive correlation for most traits. Total weight (TW) was positively correlated $(p \leq 0.05)$ with 13 variables in 2016/17: SLPB $\left(0.6^{* *}\right)$, TBL $\left(0.69^{* *}\right)$, NPB $\left(0.60^{* *}\right)$, $\operatorname{PBL}\left(0.47^{* *}\right), \operatorname{TNP}\left(0.57^{* *}\right), \operatorname{NPPB}\left(0.65^{* *}\right)$, WSMS $\left(0.70^{* *}\right), \operatorname{TSWMS}\left(0.59^{* *}\right), \operatorname{NSPB}\left(0.57^{* *}\right), \operatorname{WSPB}\left(0.91^{* *}\right)$, TWSPB $\left(0.56^{* *}\right)$, NPPPB $(0.59)$ and TNS $\left(0.65^{* *}\right)$. In 2017/18 TW was positively correlated with eleven variables: TNS $\left(0.80^{* *}\right)$, TSWMS $\left(0.68^{* *}\right)$, NPB $\left(0.56^{* *}\right)$, SLPB $\left(0.61^{* *}\right)$, NPPB $\left(0.70^{* *}\right)$, NSPB $\left(0.72^{* *}\right)$, $\operatorname{NPPPB}\left(0.62^{* *}\right), \operatorname{TSWPB}\left(0.55^{* *}\right)$, TNP $\left(0.72^{* *}\right)$, TBL $\left(0.60^{* *}\right)$, WSMS $\left(0.73^{* *}\right)$ and WSPB $\left(0.92^{* *}\right)$. Also, positive correlation was found between TW and NSPPB $\left(0.44^{* *}\right)$, SLMS $\left(0.76^{* *}\right)$, SWMS $\left(0.66^{* *}\right)$, SWBLR $\left(0.84^{* *}\right)$, NSPPB $\left(0.55^{* *}\right), \operatorname{PSPB}\left(0.61^{* *}\right)$ and PLMS $\left(0.53^{* *}\right)$. Significant $(p \leq 0.05)$ and positive correlation was also reported between TNS and NSPMS, SLPB, NPPB, NSPB, NPPPB, NSPPB, TNP, ADNL, PBL, WSMS, TSWMS, NPB, SWPB, TW, SWBLR, TBL, PSPB and WSPB in both years of experiments.

From the correlation data, heat maps were constructed (Figures 2 and 3) using euclidean distances and the UPGMA method, where in the vertical columns are the clusters of morphological traits while in the horizontal lines are the clusters of accessions. Dark red colors represent lower values while the dark blue are higher values. Figure 2 corresponds to the heat map obtained from 2016/17 data and Figure 3 was obtained with 2017/18 data. Six groups of morphological traits could be drawn in Figure 2 and five in Figure 3. In both figures, group 1 is related to the reproductive capacity of pods, defined in the Figure 2 by the characteristics NSMS, SWBLR and TW and in Figure 3 by PLMS, WSMS, TNS, TW, 
SWBLR, NSPPB and NPPB. In Figure 2, group 2 is composed by characteristics related to the distance between leaves and primary branches in the main stem (ADNL and ADBPB), while group 2 in Figure 3 includes vegetative and reproductive traits related to the main stem: average distance between leaves (ADNL), number of seeds per pod on the main stem (NSPMS) and ratio between length and width of pod on the main stem (RBLWPMS). Only one characteristic (PSMS) defines group 3 in both figures. In Figure 2, group 4 includes characteristics related with total number of seeds (TNS), proportion of leaves with branches (PBL) and percentage of seed on the primary branches (PSPB). In Figure 3, group 4 includes vegetative and reproductive traits related to the main stem (NSMS, NPMS, NPB and NLMS). Group 5 (Figure 2), includes traits related to the reproductive capacity on the main stem (TSWMS, TSWPB, PWMS and PLMS). The same group on Figure 3 is related with pod and seed size (thousand seeds weight, pod and seed size parameters) and traits that include primary branches (ALPB, SLPB and WSPPB). Group 6 is mostly defined by vegetative characteristics (TBL, ALPB, HUFF and DUF).

Cluster I represent three JKI accessions in both figures, which is discriminated by morphological groups 5 and 6 (four reproductive and five vegetative characteristics) in Figure 2. In Figure 3 Cluster I is discriminated by morphological groups 1 (seven reproductive characteristics), 4 (with three reproductive and two vegetative characteristics) and 5 (five reproductive and two vegetative characteristics). Cluster II (Figure 2) is composed by 6 accessions defined by groups 1 and 4 (five reproductive and one vegetative characteristics) and, in Figure 3, by 19 accessions and does not exhibit a defined pattern. In both figures, Cluster III with accession LM268 only, is characterized by high values in groups 1 and 5 (SWBLR, TW, PWMS, TSWPB and TSWMS) in Figure 2 and high values in group 5 and low values in groups $2-4$ in Figure 3. Cluster IV in Figure 2 does not exhibit a defined pattern. For Figure 3, Cluster IV is represented by the L. albus cultivars and is characterized by high values for all heat map in most characteristics. This cluster is defined by three groups of morphological traits: group 1 (seven reproductive variables), group 2 (three reproductive and one vegetative characteristics) and group 5 (five reproductive and two vegetative characteristics).

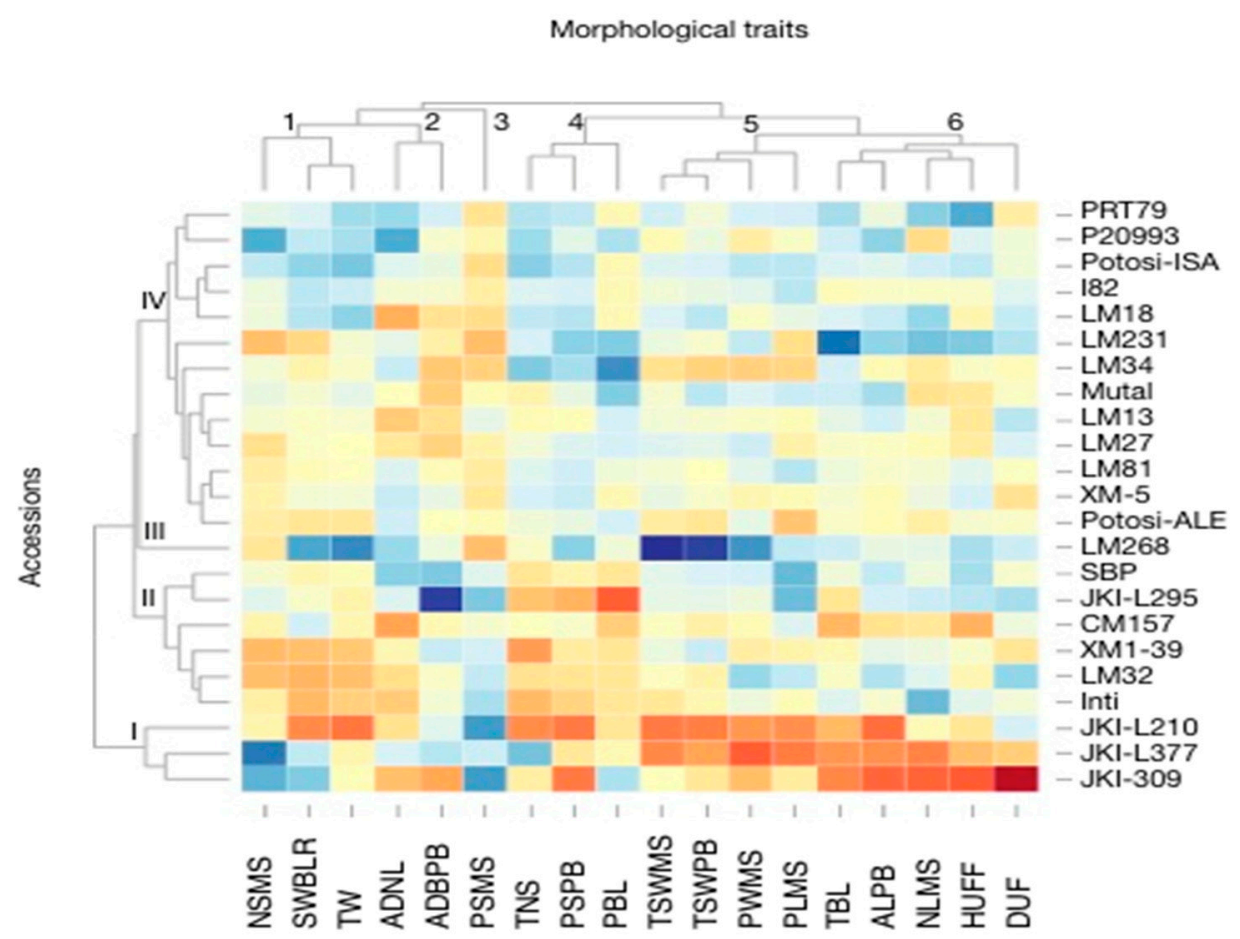

Figure 2. Heat map of the 23 accessions of L. mutabilis obtained from morphological characterization data for the 18 traits, where red and blue boxes indicate low values and high values respectively. 


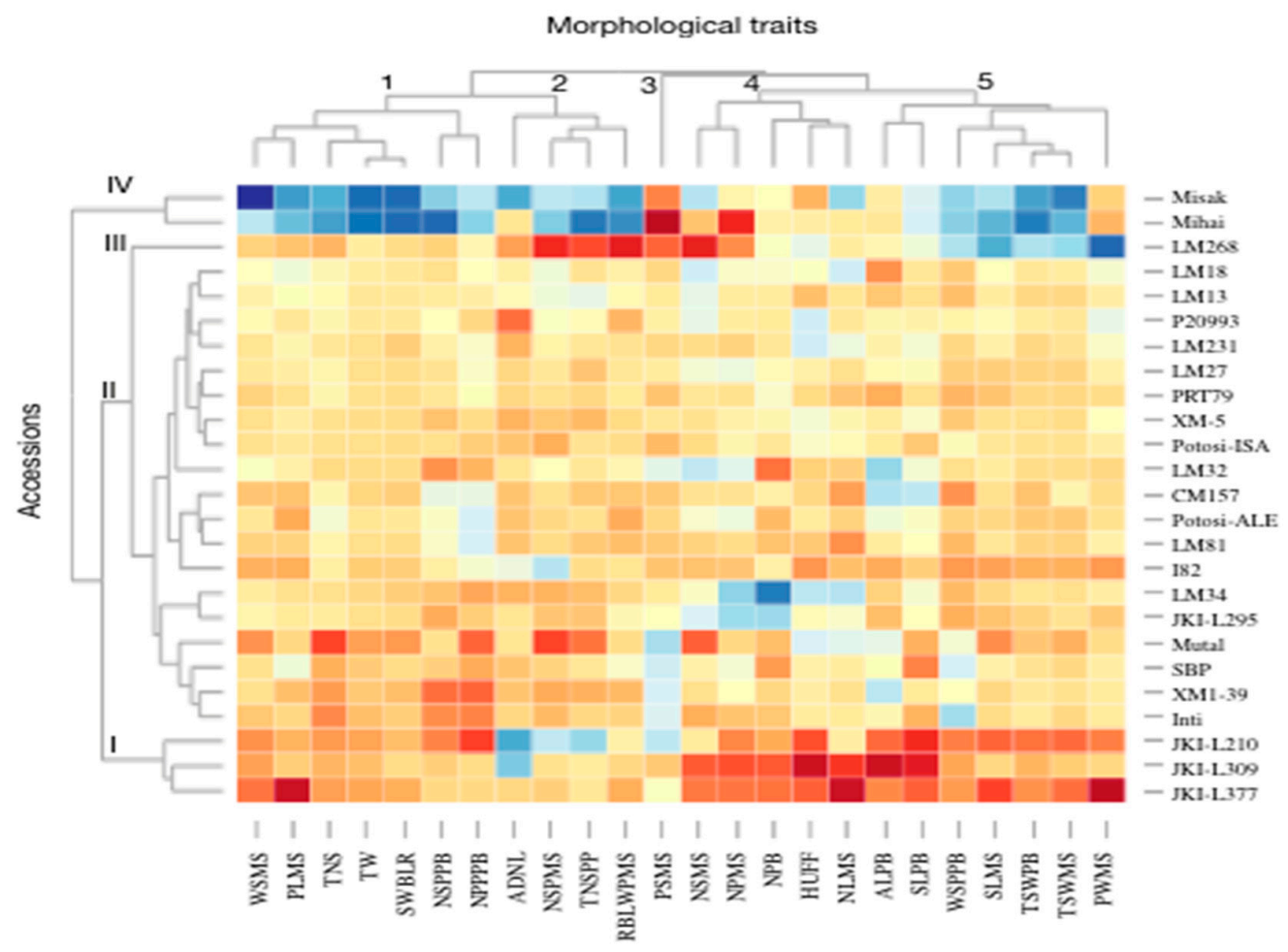

Figure 3. Heat map of the 25 accessions obtained from morphological characterization data for the 24 traits, where red and blue boxes indicate low values and high values respectively.

Principal component analysis (PCA) confirmed the cluster analysis results (Figures 2 and 3). For instance: cluster I is localized oppositely for many vectors of groups 5 and 6 (TSWMS, TSWPB, PWMS PLMS, TBL, ALPB, NLMS, HUFF, and DUF) for Figure 4 and a similar scenario can be observed in Figure 5 were the vectors defined by groups 2 and 4 (HUFF, PWMS, ALPB, NPB, NLMS, SLPB, WSPPB, SLMS, TSWMS, TSWPB, WSMS and PLMS) are in the opposite position, thus justifying the low values of these characteristics in those groups (Figures 4 and 5). In both figures the LM268 accession presents high values for many characteristics among L. mutabilis accessions. Cluster IV (Figure 5) is composed of two accessions that present high values for 17 vectors (characteristics marked in cluster analysis with blue color). In this cluster eight vectors (RBLWPMS, TSWMS, TSWPB, NSPPB, SWBLR, TW, WSMS and TNSPP) are highlighted by presenting the highest scores, with TW being the longest vector. The first three PCs projected in the biplot (Figure 4) show a clear separation of the four cluster and all together account for $75.1 \%$ of the total variation. The first component accounts for $40.3 \%$ of variation, with PWMS, TBL, PSPB, PSMS and ALPB accounting heavily for this variation. The second PC accounts for $21.4 \%$ of the variation, with TNS, NSMS and TW being the most important variables. The third PC explains another $13.4 \%$ of the variation, with the most important variables being PBL, SWBLR and PLMS. In Figure 5 the first three component explain $76.4 \%$ of total variation. For the first principal component, characteristics TW, SWBLR, TSWMS, TSWPB and TNS contribute more, explaining $43.9 \%$ of total variation. HUFF, ADNL, PWMS, TNSPP, and NSPMS are most important variables for second component; this component accounts for explanation $20.4 \%$ of variation, while NSMS, NPMSM LMS and PSMS account for $12 \%$ of variation in the third component.

\subsection{Diversity Assessed by Molecular Markers}

The six selected ISSR primers used for analysis of 23 accessions resulted in the production of 37 reproducible bands (Table 5 and Figure 6). Of those, 11 (29.7\%) bands were polymorphic and the remaining $26(70.3 \%)$ were monomorphic. The total number of bands per primer ranged between four $\left(\mathrm{GT}_{8} \mathrm{YC}\right)$ and eight $\left(\mathrm{HVH}(\mathrm{TG})_{7}\right)$, while the percentage of polymorphic bands per primer ranged from 0 
to $50 \%$. The average for each primer was 6.2 bands. Polymorphism information content (PIC), which is used in genetics as a measure of polymorphism for a marker locus, ranged from $0.23\left(\mathrm{HVH}(\mathrm{TG})_{7}\right)$ to $0.72\left(\mathrm{AG}_{8} \mathrm{YT}\right)$. Effective multiplex ratio (EMR) had its minimum value with $\mathrm{AG}_{8} \mathrm{YC}(0)$ and maximum in $\mathrm{GT}_{8} \mathrm{YC}(2.25)$. The resolving power (RP) parameter used to detect the differences between a large number of genotypes ranged from $5.48\left(\mathrm{AG}_{8} \mathrm{YT}\right)$ to $13.58\left(\mathrm{HVH}(\mathrm{TG})_{7}\right)^{2}$. The minimum and maximum values for marker index were registered for $\mathrm{AG}_{8} \mathrm{YC}(0)$ and $\mathrm{GT}_{8} \mathrm{YC}(0.54)$ primers, respectively.

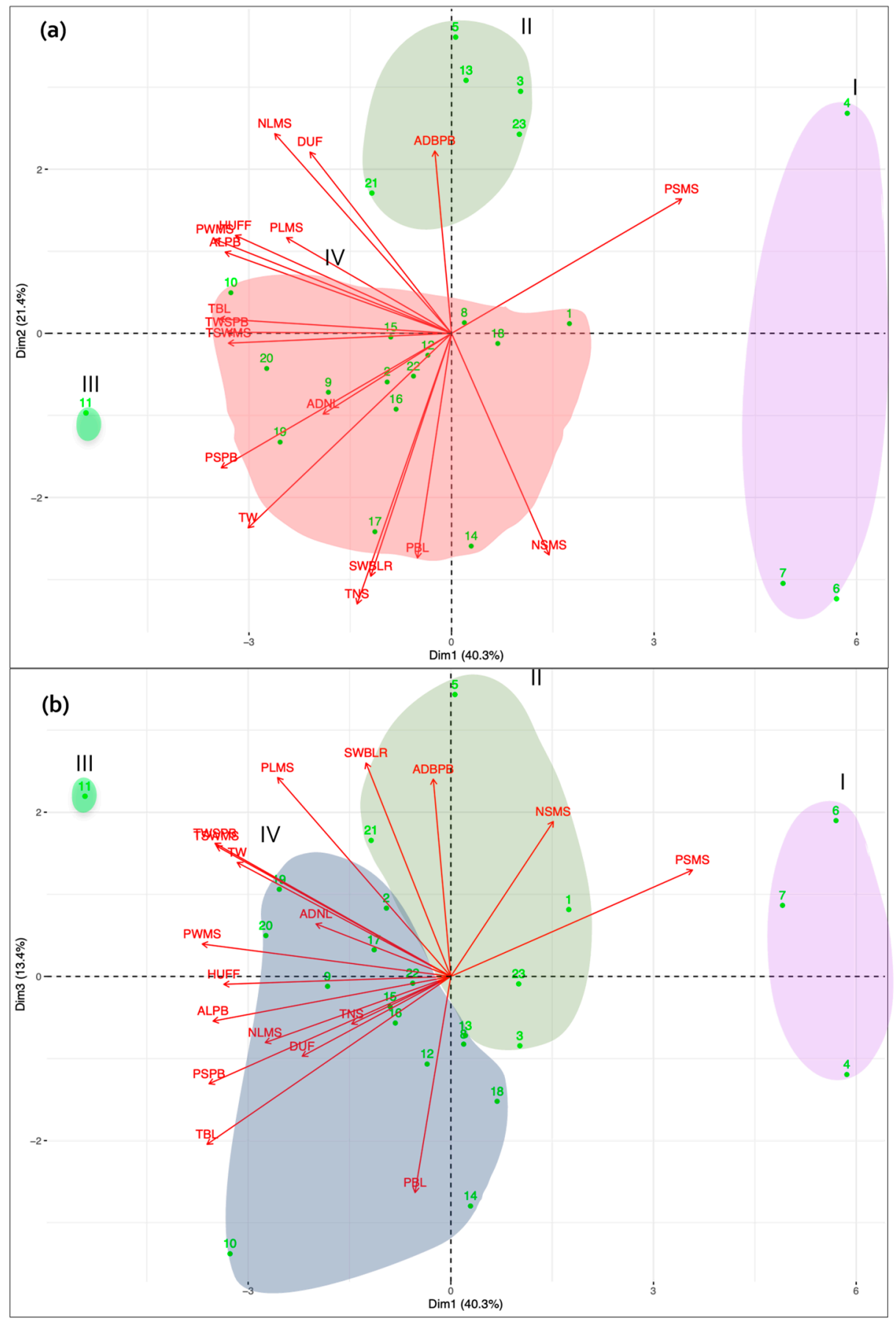

Figure 4. Representation in two dimensions (first and second dimensions-(panel a)—of principal component analysis explain $61.7 \%$ of the variability, while the inclusion of the third dimension-(panel b) - raises the three-dimensional space to explain $75.1 \%$ of the variability) of normalized original data of morphological characterization of the 23 Lupinus mutabilis accessions in a space defined by the vectors and own values. 


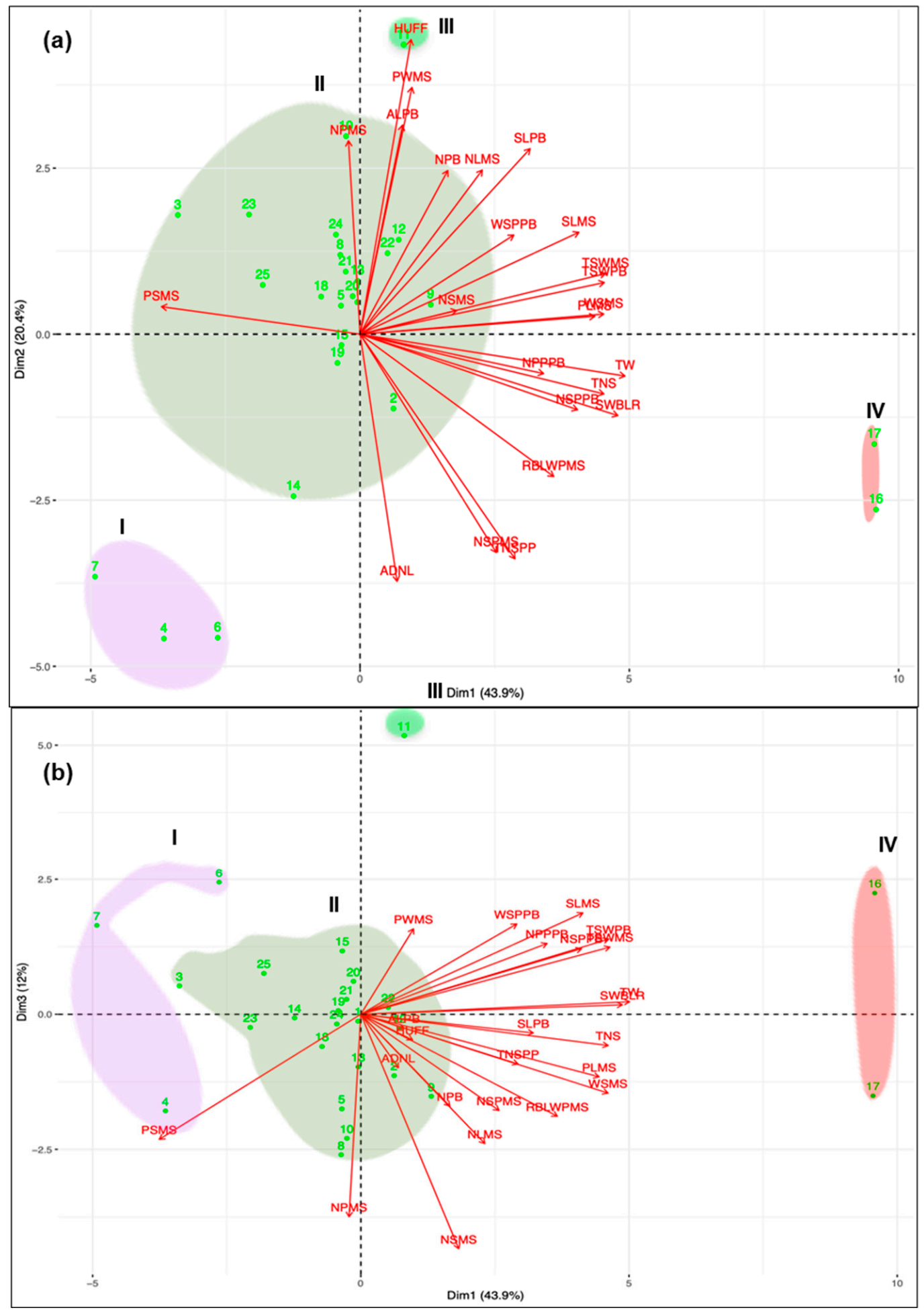

Figure 5. Representation in two dimensions (first and second dimensions—(panel a)—of principal component analysis explain $64.3 \%$ of the variability, while the inclusion of the third dimension-(panel $\mathbf{b}$ )_raises the three-dimensional space to explain $76.3 \%$ of the variability) of normalized original data of morphological characterization of the 23 Lupinus mutabilis accessions in a space defined by the vectors and own values. Numbers 1-25 encode accessions as detailed in Figure 4 (16 and 17 denote L. albus 'Mihai' and 'Misak' respectively). 
Table 5. List of Inter-Simple Sequence Repeat (ISSR) primers used in this study, their total numbers of band per primer, polymorphic and monomorphic band and polymorphism percentage per primer.

\begin{tabular}{cccccccccc}
\hline Primer & Bands & PB & MB & PB (\%) & MB (\%) & PIC & EMR & RP & MI \\
\hline HVH(TG) & 8 & 4 & 4 & 50 & 50 & 0.23 & 2 & 13.58 & 0.46 \\
$\mathrm{GA}_{8} \mathrm{YT}$ & 6 & 1 & 5 & 16.66 & 83.33 & 0.71 & 0.16 & 5 & 0.11 \\
$\mathrm{AG}_{8} \mathrm{YT}$ & 6 & 1 & 5 & 16.66 & 83.33 & 0.72 & 0.16 & 4.58 & 0.12 \\
$\mathrm{GT}_{8} \mathrm{YC}$ & 4 & 3 & 1 & 75 & 25 & 0.24 & 2.25 & 6.42 & 0.54 \\
$\mathrm{AG}_{8} \mathrm{YC}$ & 5 & 0 & 5 & 0 & 100 & 0.58 & 0 & 6 & 0.00 \\
$\mathrm{AG}_{8} \mathrm{YG}$ & 8 & 2 & 6 & 25 & 75 & 0.48 & 0.5 & 10.33 & 0.24 \\
\hline Total & 37 & 11 & 26 & & & & & & \\
Minimum & 4 & 0 & 1 & 0 & 25 & 0.23 & 0 & 4.58 & 0 \\
Maximum & 8 & 4 & 6 & 50 & 100 & 0.72 & 2.25 & 13.58 & 0.54 \\
Mean & 6.16 & 1.83 & 4.33 & 30.55 & 69.44 & 0.49 & 0.85 & 7.65 & 0.24 \\
\hline
\end{tabular}

Notes: PB-polymorphic bands; MB-monomorphic bands; MB (\%)—percentage of monomorphic bands; PB (\%) - percentage of polymorphic bands; PIC - polymorphism information content; EMR — effective multiplex ratio; $\mathrm{RP}$-resolving power; MI—-marker index. The following primers: $(\mathrm{CA})_{8} \mathrm{RY},(\mathrm{GA})_{8} \mathrm{YC},(\mathrm{GT})_{8} \mathrm{YC},(\mathrm{TCC})_{5}$ and MR were included in the screening test but were rejected during selection. Eight of these primers were previous tested [53].

ลั

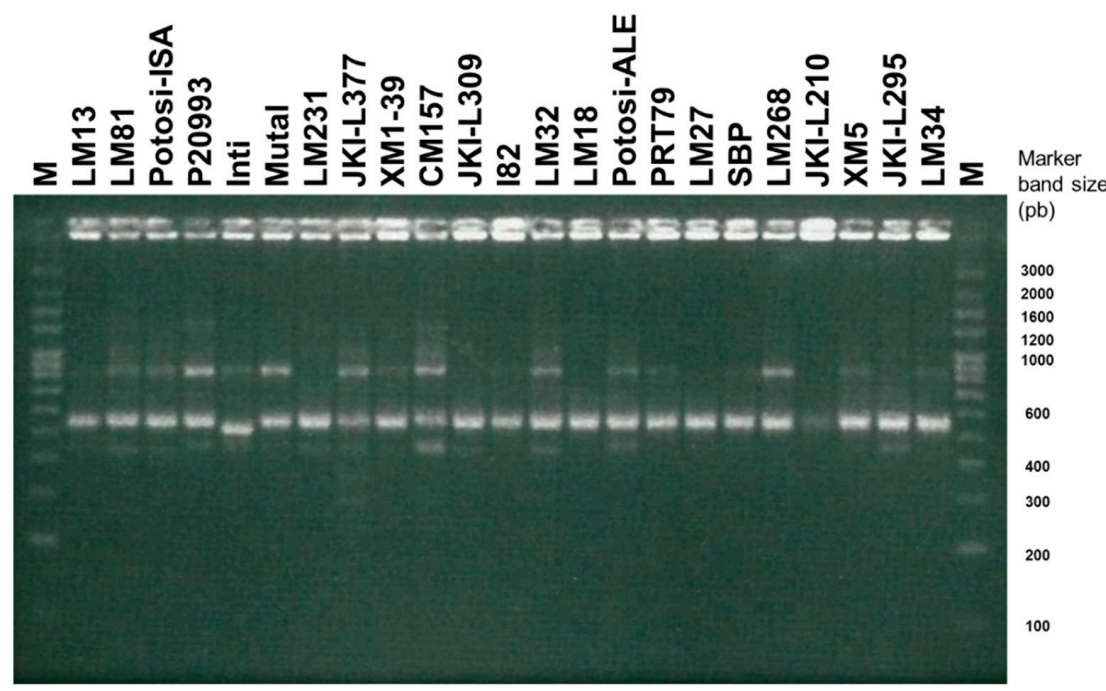

Figure 6. Example of ISSR amplification profiles for 23 Lupinus mutabilis accessions using the primer $\mathrm{GA}_{8} \mathrm{YT}$ separated on a $\%$ agarose gel. M-NZYDNA Ladder VII marker. Numbers adjacent to accession names refer to coding used in Figure 5.

The similarity matrix was used to construct a dendrogram using the UPGMA method (Figure 7). The cophenetic correlation was 0.9058603 , revealing little loss of information with transformation of similarity matrix to dendrogram. The dendrogram reveals five distinct groups. Cluster I is composed by 10 accessions of white, blue and pink flower colors and green and purple stem. Cluster II, containing 9 accessions, can be distinguished from the first group by the absence of purple stem and flower genotypes. Unlike cluster I and II, clusters III, IV and V are composed only by accessions that exhibit green stems and blue flowers. Cluster IV is represented by one accession and cluster III and V by two accessions each.

\subsection{Diversity Assessed by Genomic Traits}

Lupinus albus 'Misak' was validated as a DNA standard by comparison to Solanum lycopersicum 'Stupické' (Figure 8a,b) and Raphanus sativus 'Saxa' (data not shown) and estimated at 2C $=1.35 \pm$ $0.0076 \mathrm{pg}(1377.6 \mathrm{Mbp})$, with an average coefficient of variation of $3.47 \%$. 


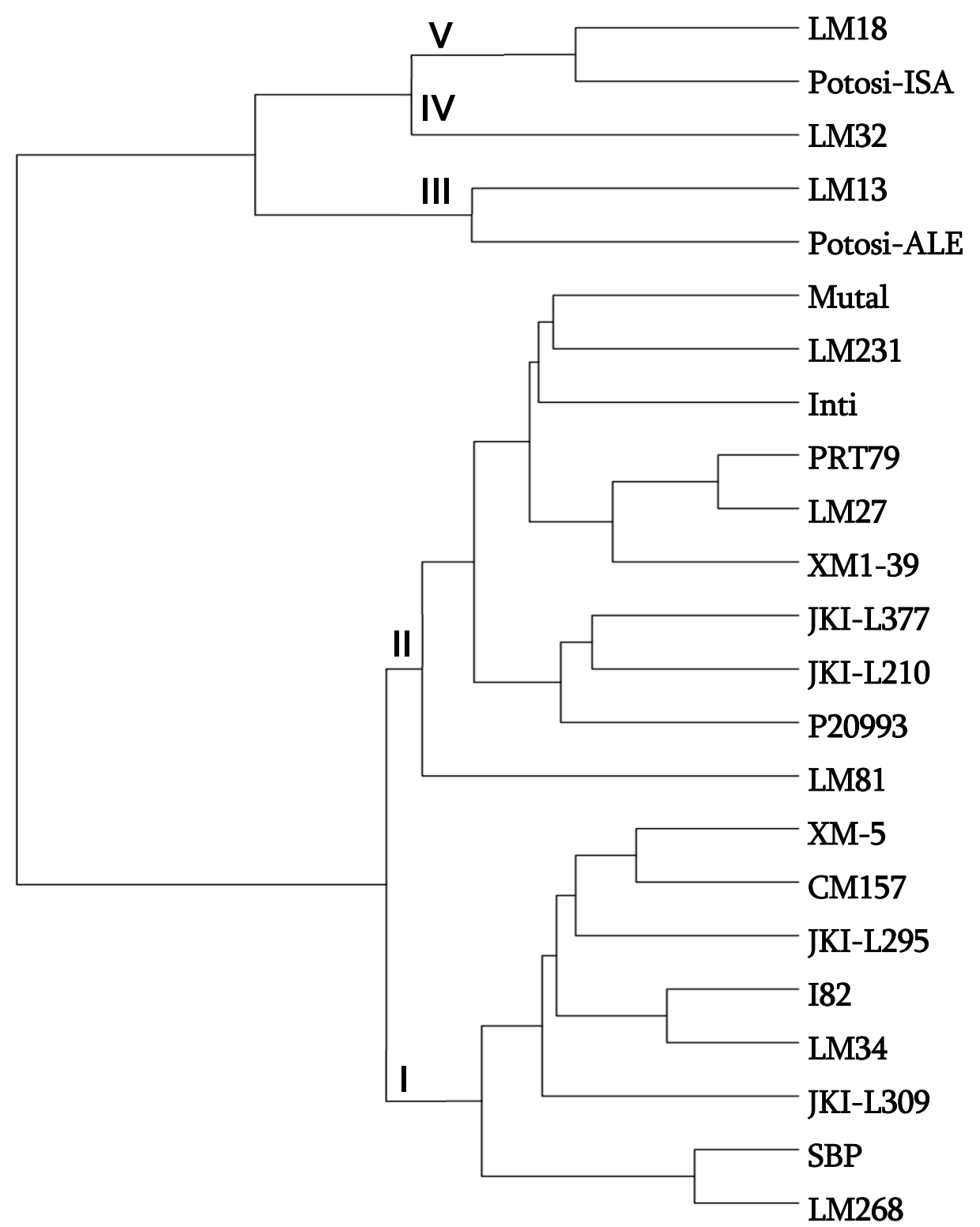

Figure 7. Dendrogram obtained by the unweighted pair group method of arithmetic mean (UPGMA) method from the coefficients of similarity (DICE) between the accessions of Lupinus mutabilis from six ISSR markers. $r=0.9058603$.

The L. mutabilis collection was thus analysed by comparison to L. albus 'Misak', as exemplified in Figure 8 (panels c,d). The average L. mutabilis genome size was estimated at $2 \mathrm{C}=2.05 \mathrm{pg}(2001.2 \mathrm{Mbp})$ with a $9.2 \%$ coefficient of variation, ranging from $1897.3 \mathrm{Mbp}$ for accession SBP to $2083.2 \mathrm{Mbp}$ for accession LM34 (Table 6). The results from a Kruskal-Wallis test performed for genome size reveal significant difference between accessions $\left(\chi^{2}=94.845, D f=23, p\right.$ value $\left.=0.000\right)$. No single accession showed to be statistically different from all the others, rather a continuum of accessions is depicted by the homogeneous groups produced (Table 6).

Genome size is an important criterion to study evolution at the intra-specific level, helping to understand conflicting pattern between morphological traits. In this study we evaluated the associations between genome size and morphological traits using Spearman correlation analysis for all 23 accessions for the two experiments. However, no single morphological trait presented strong correlation with genome size (Figure 9). 

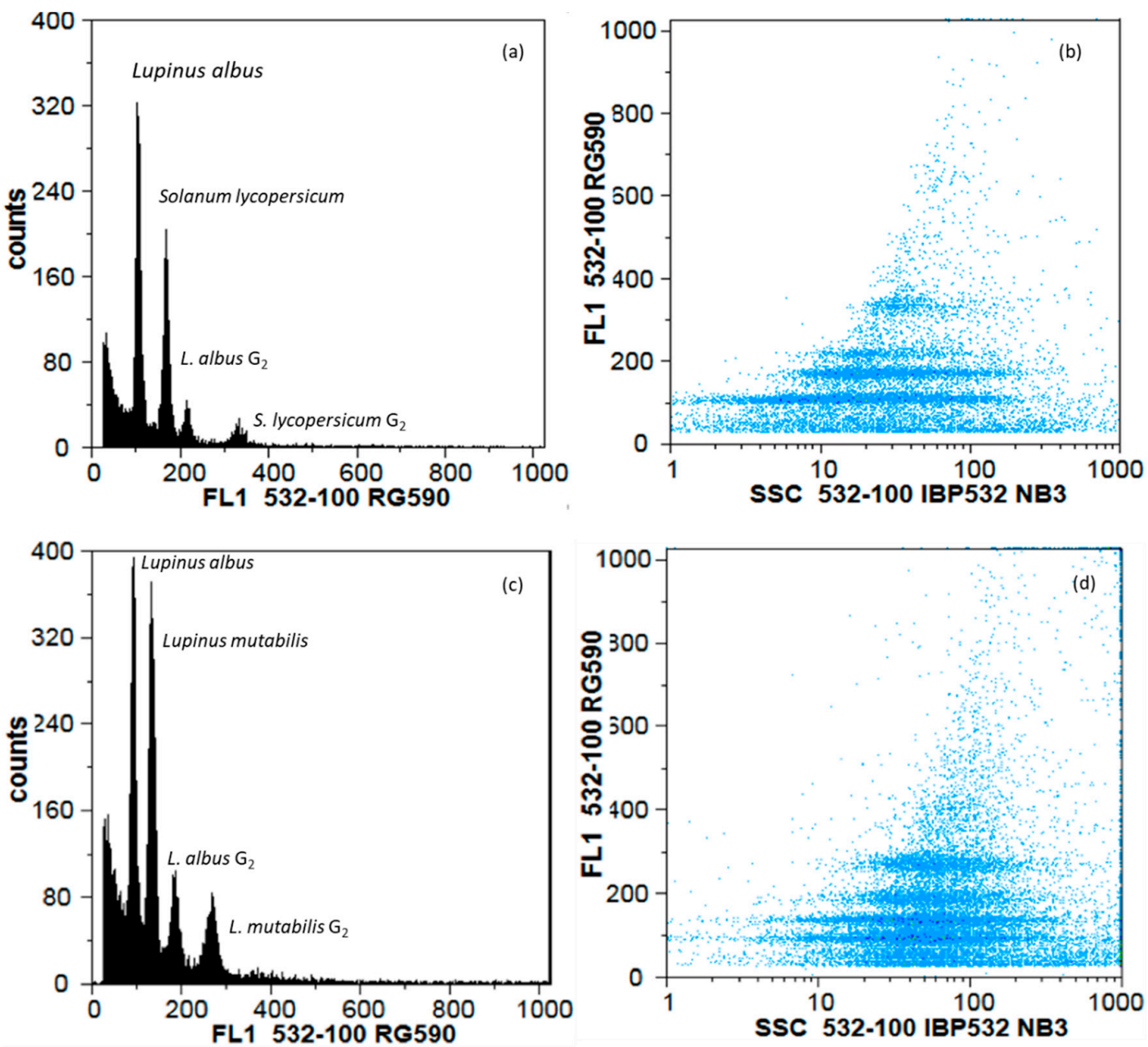

Figure 8. Flow cytometric analysis of relative fluorescence intensities (FL1) of propidium iodide-stained nuclei simultaneously isolated from: (a) and (b) Solanum lycopersicum 'Stupické' and Lupinus albus, for the validation of L. albus 'Misak' as DNA standard ( $2 \mathrm{C}=1.35 \mathrm{pg})$; (c) and (d) L. albus 'Misak' and L. mutabilis accession LM231. (a) and (c) Histogram showing relative fluorescence intensities. (b) and (d) dot plots on side scatter (SSC) versus FL1.

Table 6. Genome size of the Lupinus mutabilis accessions estimated by flow cytometry.

\begin{tabular}{cccc}
\hline \multirow{2}{*}{ Accession } & \multicolumn{2}{c}{ Genome Size (Mbp) } & \\
\cline { 2 - 3 } & Average & StDev $^{\mathbf{1}}$ & \\
& H.G. & \\
\hline SBP & 1897.3 & 18.4 & $\mathrm{a}$ \\
XM1-39 & 1907.3 & 17.0 & $\mathrm{a}$ \\
JKI-L378 & 1938.0 & 49.0 & $\mathrm{ab}$ \\
Prt-79 & 1957.4 & 16.2 & $\mathrm{ab}$ \\
JKI-L377 & 1961.4 & 16.3 & $\mathrm{ab}$ \\
Mutal & 1967.6 & 121.6 & $\mathrm{abc}$ \\
JKI-L295 & 1969.0 & 11.8 & $\mathrm{abc}$ \\
JKI-L210 & 1973.6 & 26.9 & $\mathrm{bcd}$ \\
LM13 & 1975.7 & 118.4 & $\mathrm{bcd}$ \\
JKI-L309 & 1979.7 & 37.6 & $\mathrm{bcd}$ \\
LM231 & 1984.1 & 100.4 & $\mathrm{~cd}$ \\
LM18 & 1986.4 & 54.6 & $\mathrm{cde}$ \\
XM5 & 2009.1 & 20.1 & $\mathrm{cde}$ \\
P-20993 & 2021.5 & 22.8 & $\mathrm{cde}$ \\
Potosi-ISA & 2024.3 & 36.1 & $\mathrm{cde}$ \\
Potosi-ALE & 2024.8 & 19.3 & cde \\
\hline
\end{tabular}


Table 6. Cont.

\begin{tabular}{cccc}
\hline \multirow{2}{*}{ Accession } & \multicolumn{2}{c}{ Genome Size $(\mathbf{M b p})$} & \multirow{2}{*}{ H.G. $^{2}$} \\
\cline { 2 - 3 } & Average & StDev $^{\mathbf{1}}$ & \\
\hline LM27 & 2027.7 & 23.9 & cde \\
LM32 & 2040.9 & 17.9 & de \\
CM157 & 2040.9 & 43.8 & de \\
I82 & 2041.6 & 10.9 & de \\
Inti & 2058.1 & 23.9 & ef \\
LM268 & 2078.9 & 10.1 & $\mathrm{f}$ \\
LM81 & 2080.2 & 13.1 & $\mathrm{f}$ \\
LM34 & 2083.2 & 17.3 & $\mathrm{f}$ \\
\hline
\end{tabular}

${ }^{1}$ Standard deviation; ${ }^{2}$ Homogeneous groups-accessions sharing the same letter are not statistically different.

(a)

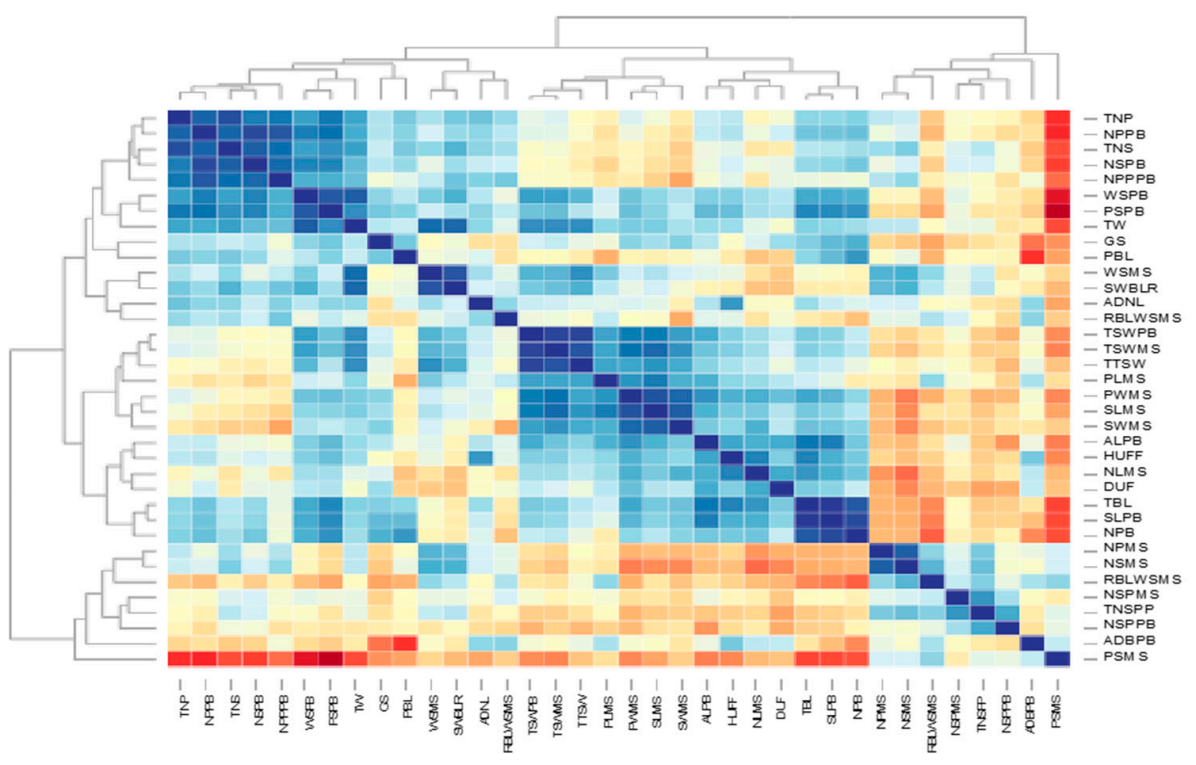

(b)

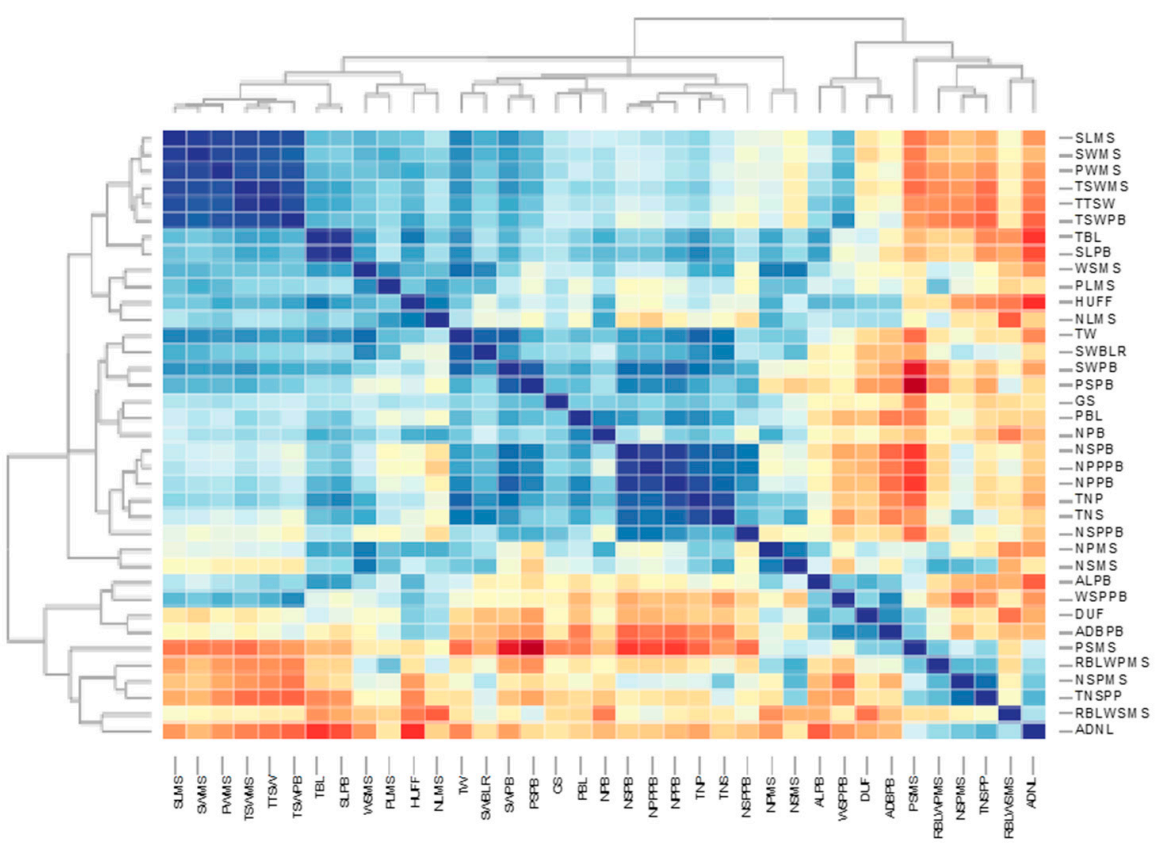

Figure 9. Heat map of the 23 Lupinus mutabilis accessions obtained from Spearman correlation among 37 morphological traits and genome size (GS) data for 2016/17 (panel a) and 2017/18 data (panel b). Dark blue boxes indicate high values and dark red depict low values. 


\section{Discussion}

To assess the diversity in a tarwi germplasm collection under Mediterranean conditions, phenotypic, genetic and genomic analyses were combined, studying morphological traits, ISSR markers and genome size. In general, the morphological traits used to evaluate accessions tested in the trials showed acceptable adaptability to the Mediterranean environment assuming that productivity projected is above $1.5 \mathrm{t} / \mathrm{ha}$, achieved under rain-fed conditions unevenly distributed during the trial periods. Similar yields were previously reported in France and Spain [54]. However, the yields obtained suggest continuing breeding to achieve higher yields. The results showed also significant differences among accessions. While additional years of field trial results would certainly improve the robustness of conclusions, the results obtained are based on traits that presented coherent values between trials.

The knowledge of the correlations between different characteristics is fundamental because it allows the accomplishment of the indirect selection of the complex characteristics that are inherited quantitatively and influenced by genetic effects [43]. In this work we report positive and significant correlation between many variables. Characteristics such as total seed weight (TW) and total number of seeds (TNS) are very important and are directly related to characteristics of reproductive development. Accession LM268 presented higher values for TW and LM34, P20993 and LM18 for TNS. Therefore, these two features can work as criteria of selection in our collection for the breeding programme or to choose the most adapted. Talhinhas et al. [43] verified positive correlation between total weight with plant height, pod width, number of primary branches, proportion of seeds on the primary branches, total number of seeds and number of pods per primary branch in L. angustifolius. Georgieva and Kosev [55] also found positive correlation between thousand seed weight and plant height. Clements et al. [56] reported positive correlation between weight and plant height of 1000 seeds in L. pilosus. Heritability is a parameter widely used by breeders to genotype selection based on phenotypic expression [57]. Morphological traits exhibiting high values of heritability are chosen for the selection based on this parameter $[43,58]$. High heritability values enable the identification of important features to be selected for genetic breeding. Concerning our study, tarwi accessions can be selected based on the following traits: TW, SLMS, NPMS, NLMS, TNS, HUFF, PSMS, TSWMS, TSWPB, WSPPB, PWMS, SWBLR, TBL, ALPB, ADNL, SLPB, WSMS, WSPB, NPB, and NPPB. Similar results were noticed by Talhinhas [53] for SLMS, NLMS, HUFF, PSMS, TNS, and TW in L. albus, L. angustifolius and L. luteus. Our results also corroborate those by Georgieva and Kosev [55], who found high values of heritability for pod length and total number of seeds in L. albus and L. luteus.

In the present study several accessions stood out due to their superior performance in various traits. Along with accession LM268, accessions LM18, LM27, P20993, Potosi-ISA, PRT79 and I82 were the most efficient in converting vegetative growth to seed production, although lagging behind the performance of L. albus. Accession LM268 was the only tarwi accession to produce more yield on the primary branches than on the main stem, following the pattern of L. albus cultivars.

An important result worth highlighting is that most of the L. mutabilis accessions studied concentrate their production on the main stem. This characteristic is very important because it allows adaptability of tarwi to poor growth (soil and/or climatic) conditions. This characteristic may also prove useful to avoid the indeterminate growth habit of tarwi, particularly problematic in areas without summer drought. Breeding programmes should be directed for improving levels of production on the main stem and primary branches for good soil/climate conditions but with summer drought and focus on more determinate growth plants (those concentrating production on the main stem) both for marginal areas and for areas without summer drought. To the latter, accessions such as JKI-L295 and JKI-L210 stand out, as they produced over $80 \%$ of their yield on the main stem while attaining relatively high yields (ca. $10 \mathrm{~g}$ per plant).

The use of molecular markers in genetic diversity studies at the intra and inter specific levels proved useful in a wide range of species $[59,60]$. In this study we assessed the efficiency of ISSR markers for the characterisation of genetic diversity of L. mutabilis accessions. This technique is important because it allows to make a broad screening of a collection. SSR markers are not optimised yet for 
L. mutabilis and the transfer of such markers from other Fabaceae to tarwi did not prove successful [61], leaving ISSRs as a valid tool for preliminary screening of germplasm collections. All six primers used in this investigation revealed a polymorphism of $30.55 \%$ for all 23 accessions. Bussell et al. [62] establish $20 \%$ as minimum of monomorphic band percentage for genetic diversity study and our study reveals $69.44 \%$ monomorphic bands. Similar results were reported by Chirinos-Arias et al. [37] assessing genetic variability among 30 accessions of L. mutabilis using eight ISSR markers, finding a total polymorphism of $58.82 \%$. The high level of polymorphism obtained in our study is in accordance with those authors. The parameters PIC, EMR, MI and RP were used to evaluate the efficiency of ISSR primers. However, to the best of our knowledge, there are no studies on L. mutabilis assessing the effective multiplex ratio, polymorphic information content, marker index and resolving power. Results show high probability in detecting polymorphism PIC (0.72), for the primer $\mathrm{HVH}\left(\mathrm{TG}_{7}\right)$. The $\mathrm{AG}_{8} \mathrm{YG}$ primer stood out as presenting a high RP value (13.58), being more qualified to distinguish accessions. The highest value of EMR (2.25) was obtained with primer $\mathrm{AG}_{8} \mathrm{YC}$, revealing this to be most efficient. The primer $\mathrm{AG}_{8} \mathrm{YC}$ proved to be the most useful because it presented the highest value of MI (0.54). Several studies have been undertaken based on these techniques for selecting efficient ISSR primers in different species [63-67].

The 23 tarwi accessions were divided in five main genetic groups using cluster analysis by the UPGMA method (Figure 5). However, morphological characteristics such as stem and flower colour did not exhibit regular relationships in different clusters. The existence of several distinct groups that aggregate different stem and flower colours probably reflects few differences on the genetic constitution of the accessions. On the other hand, the distinct groups can reflect into distinct morphological characteristics and variations. Talhinhas [53] suggested that low intra-specific diversity in tarwi can be related to the fact that all the accessions originated from a limited number of landraces, reflecting the recent domestication genetic bottleneck effect that is estimated to have occurred no later than 2600 years before the present time in L. mutabilis [16]. Similar result was found by Chen et al. [68] in the research done on the 105 genotypes on Vigna unguiculata. In this work we verify that the genetic variability is not correlated with phenotypic variability, indicating the need for incorporation of more molecular markers. Similar results have been reported in other species. Previous studies performed by Galek et al. [14] also did not find a relation between genetic and morphological variability in accessions of L. mutabilis. In a study aiming to evaluate genetic diversity of Nelumbo using analyses of Randomly Amplified Polymorphic DNA (RAPD) and ISSR markers, Li et al. [69] found low correlation between molecular and morphological data. Talhinhas et al. [44] assessing genetic diversity in Lupinus luteus using ISSR and Amplified Fragment Length Polymorphism (AFLP) markers did not find any correlation between morphological and molecular data.

In this work we report the existence of significant differences in the intraspecific genome size (GS) variability in 23 accessions of Lupinus mutabilis. Our results reveal that the GS ranged from $1.94 \mathrm{pg} / 2 \mathrm{C}$ to $2.13 \mathrm{pg} / 2 \mathrm{C}$. Naganowska et al. [70], also employing flow cytometry to analyse propidium iodide-stained nuclei, evaluated the nuclear DNA content variation in the genus Lupinus and found $1.90 \mathrm{pg} / 2 \mathrm{C}$ for Lupinus mutabilis, although a single accession was used in that study. To the best of our knowledge, our study is the first L. mutabilis genome size intra-specific analysis, depicting an overall average size of $2.05 \mathrm{pg}$ (2001.2 Mbp). Several studies have reported intraspecific differences in genome size in various species such as Glycine max, Linum austriacum and Zea mays [33,71,72]. The intraspecific variation in genome size can result from repetitive/non-coding regions, hence increasing or decreasing in satellite DNA transposable elements and ribosomal genes [73]. There are studies pointing that transposable elements are largely responsible for notable differences in genome sizes. For instance, in maize, transposable elements are responsible for $85 \%$ of differences [74]. According to Petrov [75] these elements have potential of multiplicity of $0.1-1 \mathrm{Mbp}$ in a single generation. The satellite DNA can also contribute greatly to genome size differences [76]. Meanwhile, Garrido-Ramos [74] refer that genomic content variation in plants which are affected by satellite DNA can range from $0.1 \%$ to $36 \%$. Small variation of $3.5 \%$ in nuclear DNA have been associated with ribosomal genes [77]. The maximum 
variation of nuclear DNA content obtained in the present research was $9.2 \%$, a value much higher than the $2 \%$ maximum genome size variability reported for soybean [71] but smaller than the $36 \%$ variation reported for maize [72]. In light of this discussion, one may discard the possibility that differences in L. mutabilis genome size are caused by the transposable elements. Only a detailed study could unravel whether this variation is due to repeated sequence differences in satellite DNA or ribosomal genes.

Data on 37 morphological traits and genome size measurement were plotted and no correlation was observed. This is not a surprise, as similar results were also reported from other studies. For instance, Oney and Tabur [31] did not find correlation between genome size and morphological traits on the Brachypodium distachyon collected in different locations in Turkey. Realini et al. [72] observed weak association between genome size and morphological traits in maize. Recently Basak et al. [78] assessing the variation of morphological traits with the genome size in turnip found no correlation. This lack of association between morphological traits and genome size suggests that other factors are determinant on the control of such characteristics, reinforcing the view that genome size variations are mainly related to non-coding regions [79].

\section{Conclusions}

The agronomic performance of L. mutabilis in Portuguese conditions was good, assuming that the assay was conducted under rain-fed conditions. Our results highlight the accession LM268 with larger seeds and a total thousand seeds weight similar to L. albus, while also achieving the highest yield and being the only tarwi accession producing more on the primary branches than on the main stem. While high yields in lupins depend on the capacity of the plants to produce large amounts of pods and seeds on lateral branches, the indeterminate growth habit of tarwi can be undesirable, either in areas without summer drought or, on the contrary, in areas with limited growing periods where further vegetative growth may impair pod filling. To this end, JKI-L295 accession present high yield concentrated on the main stem, suggesting a semi-determinate development pattern. In either case, this accession is a key point for continued breeding. In fact, the present study has shown that tarwi is still behind white lupin in terms of its adaptability to Mediterranean conditions, namely concerning yield. The genetic diversity revealed in this study, however, prompts further breeding opportunities. Molecular marker and genome size analyses have revealed important levels of genetic/genomic diversity, which could not be related to phenotypic/morphologic diversity. This illustrates a scenario of recent domestication in the absence of a gene flow to wild relatives suggesting, however, that further exploitation of genetic diversity in this tarwi collection is possible and may provide additional sources of useful agronomic traits.

Supplementary Materials: The following are available online at http://www.mdpi.com/2073-4395/10/1/21/s1: Figure S1: Meteorological data collected at Tapada da Ajuda (Lisbon) during 2016/17 and 2017/18: (a) monthly average of daily average temperatures compared to the 30-year climatological normal values for Lisbon; (b) monthly rainfall compared to the 30-year climatological normal values for Lisbon; (c) soil water balance (including daily rainfall values), Table S1: Analysis of morphological traits by Kruskal Wallis test 2016/17 and 2017/18, Tables S2 and S3: Correlation matrix between morphological traits calculated for the 23 Lupinus mutabilis accessions under study (values greater than $85 \%$ are highlighted) for the experiment carried out in 2016/17 and 2017/18, respectively.

Author Contributions: Conceptualization, N.G. and J.N.-M.; Formal analysis, N.G., S.A. and P.T.; Funding acquisition, J.N.-M.; Investigation, N.G., S.A. and P.T.; Methodology, N.G., P.T. and J.N.-M.; Project administration, J.N.-M.; Supervision, P.T. and J.N.-M.; Writing—original draft, N.G.; Writing—review and editing, P.T. All authors have read and agreed to the published version of the manuscript.

Funding: This research was funded by the European Union (H2020/720726, LIBBIO project) and by Fundação para a Ciência e a Tecnologia, Portugal (UID/AGR/04129/2013, LEAF).

Acknowledgments: The authors acknowledge Julius Kühn-Institut for providing biological material, Instituto Português do Mar e da Atmosfera (IPMA) for meteorological data from the Tapada da Ajuda (Lisboa) weather station and Lusosem for the support provided in field trial conduction.

Conflicts of Interest: The authors declare no conflict of interest. The funders had no role in the design of the study; in the collection, analyses, or interpretation of data; in the writing of the manuscript; or in the decision to publish the results. 


\section{References}

1. Eastwood, R.J.; Drummond, C.S.; Schifino-Wittmann, M.T.; Hughes, C.E. Diversity and evolutionary history of lupins insights from new phylogenies. In Lupins for Health and Wealth. Proceedings of the 12th International Lupin Conference, Fremantle, Australia, 14-18 September 2008; Palta, J.A., Berger, J.B., Eds.; International Lupin Association: Canterbury, New Zealand, 2008; pp. 346-354.

2. Gladstones, J.S. Lupins of the Mediterranean Region and Africa; Western Australian Department of Agriculture and Food: Kensington, Australia, 1974; Volume 26, pp. 1-48.

3. Gladstones, J.S. Present situation and potential of Mediterranean/African Lupinus for crop production. In Proceedings of the Third International Lupin Conference, La Rochelle, France, 4-8 June 1984; pp. 18-37.

4. Bellido, L.L.; Garcia, M.F. El Altramuz; Ministerio de Agricultura y Alimentación: Córdoba, Spain, 1991.

5. Caligari, P.D.S.; Römer, P.; Rahim, M.A.; Huyghe, C.; Neves-Martins, J.; Sawicka-Sienkiewicz, E.J. The Potential of Lupinus mutabilis as a crop In Linking Research and Marketing Opportunities for Pulses in the 21st Century; Kluwer Academic Publishers: Dordrecht, The Netherlands, 2000; Volume 34, pp. 569-574.

6. Jacobsen, S.E.; Mujica, A. El Tarwi (Lupinus mutabilis Sweet) y sus parientes silvestres. Bot. Econ. Andes Cent. 2006, 28, 458-482.

7. Wink, M. Quinolizidine alkaloids. In Methods in Plant Biochemistry, 8th ed.; Waterman, P., Ed.; Academic Press: London, UK, 1993; pp. 197-239.

8. Wink, M.; Meißner, C.; Witte, L. Patterns of quinolizidine alkaloids in 56 species of the genus Lupinus. Phytochemistry 1995, 38, 139-153. [CrossRef]

9. Carvajal-Larenas, F.E.; Linnemann, A.R.; Nout, M.J.R.; Koziol, M.; van Boekel, M.A.J.S. Lupinus mutabilis: Composition, uses, toxicology, and debittering. Rev. Food Sci. Nutr. 2016, 56, 1454-1487. [CrossRef] [PubMed]

10. Borek, S.; Ratajczak, W.; Ratajczak, L. Regulation of storage lipid metabolism in developing and germinating lupin (Lupinus spp.) seeds. Acta Physiol. Plant. 2015, 37, 119. [CrossRef]

11. Villacrés, E.; Peralta, E.; Álvarez, M. Recetario Chochos en Su Punto; INIAP Santa Catalina: Quito, Ecuador, 2003; p. 43.

12. Martins, J.M.N.; Talhinhas, P.; De Sousa, R.B. Yield and seed chemical composition of Lupinus mutabilis in Portugal. Rev. Ciênc. Agrar. 2016, 39, 518-525. [CrossRef]

13. Santos, C.N.; Ferreira, R.B.; Teixeira, A.R. Seed Proteins ofLupinus mutabilis. J. Agric. Food Chem. 1997, 45, 3821-3825. [CrossRef]

14. Galek, R.; Sawicka-Sienkiewicz, E.; Zalewski, D.; Stawiński, S.; Spychała, K. Searching for low alkaloid forms in the Andean lupin (Lupinus mutabilis) collection. Czech J. Genet. Plant Breed. 2017, 53, 55-62. [CrossRef]

15. Martínez Flores, L.A.; Ruivemkamp, G.; Jongerden, J. Plant breeding and social rationality: The unintended effects of the release of a lupino seed (Lupinus mutabilis Sweet) in Ecuador. Antípod. Rev. Antropol. Arqueol. 2016, 26, 71-91.

16. Atchison, G.W.; Nevado, B.; Eastwood, R.J.; Contreras-Ortiz, N.; Reynel, C.; Madriñán, S.; Filatov, D.A.; Hughes, C.E. Lost crops of the Incas: Origins of domestication of the Andean pulse crop tarwi, Lupinus mutabilis. Am. J. Bot. 2016, 103, 1592-1606. [CrossRef]

17. Galek, R.A.; Kozak, B.; Biela, A.; Zalewski, D.; Sawicka- Sienkiewicz, E.; Spychała, K.; Stawiń;ski, S. Seed coat thickness differentiation and genetic polymorphism for Lupinus mutabilis Sweet breeding. Turk. J. Field Crops 2016, 21, 305-312.

18. Gross, R. El Cultivo y la Utiliziación del Lupinus mutabilis Sweet; FAO: Rome, Italy, 1982.

19. Xiao, L.; Ge, X.; Gong, X.; Hao, G.; Zheng, S. ISSR Variation in the Endemic and Endangered Plant Cycas guizhouensis (Cycadaceae). Ann. Bot. 2004, 94, 133-138. [CrossRef] [PubMed]

20. Almajali, D.; Abdel-Ghani, A.H.; Migdadi, H. Evaluation of genetic diversity among Jordanian fig germplasm accessions by morphological traits and ISSR markers. Sci. Hortic. 2012, 147, 8-19. [CrossRef]

21. Ahmed, B.A.; Ghada, B.; Laila, E.; Hafid, A.; Bouchaib, K.; Amel, S.-H. Use of morphological traits and microsatellite markers to characterize the Tunisian cultivated and wild figs (Ficus carica L.). Biochem. Syst. Ecol. 2015, 59, 209-219. [CrossRef]

22. Ferreira, J.; Garcia-Gonzalez, C.; Tous, J.; Rovira, M. Genetic diversity revealed by morphological traits and ISSR markers in hazelnut germplasm from northern Spain. Plant Breed. 2010, 129, 435-441. [CrossRef] 
23. Yuan, C.-Y.; Wang, P.; Chen, P.-P.; Xiao, W.-J.; Zhang, C.; Hu, S.; Zhou, P.; Chang, H.-P.; He, Z.; Hu, R.; et al. Genetic diversity revealed by morphological traits and ISSR markers in 48 Okras (Abelmoschus escullentus L.). Physiol. Mol. Boil. Plants 2015, 21, 359-364. [CrossRef]

24. Elameen, A.; Larsen, A.; Klemsdal, S.S.; Fjellheim, S.; Sundheim, L.; Msolla, S.; Masumba, E.; Rognli, O.A. Phenotypic diversity of plant morphological and root descriptor traits within a sweet potato, Ipomoea batatas (L.) Lam., germplasm collection from Tanzania. Genet. Res. Crop Evol. 2011, 58, 397-407. [CrossRef]

25. Pagnotta, M.A.; Mondini, L.; Codianni, P.; Fares, C. Agronomical, quality, and molecular characterization of twenty Italian emmer wheat (Triticum dicoccon) accessions. Genet. Res. Crop Evol. 2009, 56, 299-310. [CrossRef]

26. Miller, J.C.; Tanksley, S.D. RFLP analysis of phylogenetic relationships and genetic variation in the genus Lycopersicon. Theor. Appl. Genet. 1990, 80, 437-448. [CrossRef]

27. Heidari, E.F.; Rahimmalek, M.; Mohammadi, S.; Ehtemam, M.H. Genetic structure and diversity of ajowan (Trachyspermum ammi) populations based on molecular, morphological markers, and volatile oil content. Ind. Crops Prod. 2016, 92, 186-196. [CrossRef]

28. Kalpana, D.; Choi, S.H.; Choi, T.K.; Senthil, K.; Lee, Y.S. Assessment of genetic diversity among varieties of mulberry using RAPD and ISSR fingerprinting. Sci. Hortic. 2012, 134, 79-87. [CrossRef]

29. Vanijajiva, O. Genetic variability among durian (Durio zibethinus Murr.) cultivars in the Nonthaburi province, Thailand detected by RAPD analysis. J. Agric. Technol. 2011, 7, 1105-1114.

30. Zietkiewicz, E.; Rafalski, A.; Labuda, D. Genome Fingerprinting by Simple Sequence Repeat (SSR)-Anchored Polymerase Chain Reaction Amplification. Genomics 1994, 20, 176-183. [CrossRef]

31. Oney, S.; Tabur, S. Genome size and morphological variation in Brachypodium distachyon along altitudinal levels. Pak. J. Bot. 2018, 50, 1923-1933.

32. Petrova, G.; Dzhambazova, T.; Moyankova, D.; Georgieva, D.; Michova, A.; Djilianov, D.; Möller, M. Morphological variation, genetic diversity and genome size of critically endangered Haberlea (Gesneriaceae) populations in Bulgaria do not support the recognition of two different species. Plant Syst. Evol. 2014, 300, $29-41$. [CrossRef]

33. Sheidai, M.; Afshar, F.; Keshavarzi, M.; Talebi, S.-M.; Noormohammadi, Z.; Shafaf, T. Genetic diversity and genome size variability in Linum austriacum (Lineaceae) populations. Biochem. Syst. Ecol. 2014, 57, $20-26$. [CrossRef]

34. Yan, J.; Zhang, J.; Sun, K.; Chang, D.; Bai, S.; Shen, Y.; Huang, L.; Zhang, J.; Zhang, Y.; Dong, Y. Ploidy Level and DNA Content of Erianthus arundinaceus as Determined by Flow Cytometry and the Association with Biological Characteristics. PLoS ONE 2016, 11, e0151948. [CrossRef]

35. Wu, Y.Q.; Taliaferro, C.M.; Bai, G.H.; Martin, D.L.; Anderson, J.A.; Anderson, M.P.; Edwards, R.M. Genetic Analyses of Chinese Accessions by Flow Cytometry and AFLP Markers. Crops Sci. 2006, 46, 917. [CrossRef]

36. Obermayer, R.; Świecicki, W.K.; Greilhuber, J. Flow Cytometric Determination of Genome Size in some Old World Lupinus Species (Fabaceae). Plant Biol. 1999, 1, 403-407. [CrossRef]

37. Chirinos-Arias, M.C.; Jiménez, J.E.; Vilca-Machaca, L.S. Analysis of Genetic Variability among thirty accessions of Andean Lupin (Lupinus mutabilis Sweet) using ISSR molecular markers. Sci. Agropecu. 2015, 6, 17-30. [CrossRef]

38. Galek, R.; Kozak, B.; Sawicka-Sienkiewicz, E.; Zalewski, D.; Nowosad, K. Searching for the most useful genotypes of Lupinus mutabilis sweet for breeding purpose. Electron. J. Pol. Agric. Univ. 2017, 20. [CrossRef]

39. Allen, R.G.; Pereira, L.S.; Raes, D.; Smithm, M. Crop Evapotranspiration-Guidelines for Computing Crop Water Requirements_FAO Irrigation and Drainage Paper 56; Food and Agriculture Organization of the United Nations: Rome, Italy, 1998.

40. Talhinhas, P.; Leitão, J.; Martins, J. Collection of Lupinus angustifolius L. germplasm and characterisation of morphological and molecular diversity. Genet. Res. Crop Evol. 2006, 53, 563-578. [CrossRef]

41. IBPGR. Lupin Descriptors; IBPGR: Rome, Italy, 1981.

42. Conover, W.J.; Iman, R.L. Rank Transformations as a Bridge between Parametric and Nonparametric Statistics. Am. Stat. 1981, 35, 124.

43. Mazid, M.; Rafii, M.; Hanafi, M.M.; Rahim, H.; Shabanimofrad, M.; Latif, M.A. Agro-morphological characterization and assessment of variability, heritability, genetic advance and divergence in bacterial blight resistant rice genotypes. S. Afr. J. Bot. 2013, 86, 15-22. [CrossRef] 
44. Talhinhas, P.; Neves-Martins, J.; Leitão, J. AFLP, ISSR and RAPD markers reveal high levels of genetic diversity among Lupinus spp. Plant Breed. 2003, 122, 507-510. [CrossRef]

45. Sehgal, D.; Rajpal, V.R.; Raina, S.N.; Sasanuma, T.; Sasakuma, T. Assaying polymorphism at DNA level for genetic diversity diagnostics of the safflower (Carthamus tinctorius L.) world germplasm resources. Genetica 2009, 135, 457-470. [CrossRef]

46. Varshney, R.K.; Chabane, K.; Hendre, P.S.; Aggarwal, R.K.; Graner, A. Comparative assessment of EST-SSR, EST-SNP and AFLP markers for evaluation of genetic diversity and conservation of genetic resources using wild, cultivated and elite barleys. Plant Sci. 2007, 173, 638-649. [CrossRef]

47. Kumar, J.; Agrawal, V. Assessment of genetic diversity, population structure and sex identification in dioecious crop, Trichosanthes dioica employing ISSR, SCoT and SRAP markers. Heliyon 2019, 5, e01346. [CrossRef]

48. Dolezel, J.; Sgorbati, S.; Lucretti, S. Comparison of three DNA fluorochromes for flow cytometric estimation of nuclear DNA content in plants. Physiol. Plant. 1992, 85, 625-631. [CrossRef]

49. Bennett, M.D.; Smith, J.B. Nuclear DNA Amounts in Angiosperms. Philos. Trans. R. Soc. B Boil. Sci. 1976, 274, 227-274. [CrossRef]

50. Loureiro, J.; Rodriguez, E.; Doležel, J.; Santos, C. Two New Nuclear Isolation Buffers for Plant DNA Flow Cytometry: A Test with 37 Species. Ann. Bot. 2007, 100, 875-888. [CrossRef]

51. Doležel, J.; Bartoš, J. Plant DNA Flow Cytometry and Estimation of Nuclear Genome Size. Ann. Bot. 2005, 95, 99-110. [CrossRef] [PubMed]

52. Doležel, J.; Bartoš, J.; Voglmayr, H.; Greilhuber, J. Nuclear DNA content and genome size of trout and human. Cytometry 2003, 51, 127-128. [CrossRef] [PubMed]

53. Talhinhas, P. Caracterização de Germoplasma do Género Lupinus, Avaliação da Resistência à Antracnose e Estudos da Diversidade e Taxinomia do Agente Causal (Colletotrichum Acutatum Simmonds ex Simmonds). Ph.D. Thesis, Universidade Técnica de Lisboa, Lisboa, Portugal, 2002.

54. Hardy, A.; Huyghe, C.; Rahim, M.A.; Roemer, P.; Neves-Martins, J.M.; Sawicka-Sienkiewicz, E.; Caligari, P.D.S. Effects of genotype and environment on architecture and flowering time of indeterminate Andean lupins (Lupinus mutabilis Sweet). Aust. J. Agric. Res. 1998, 49, 1241. [CrossRef]

55. Georgieva, N.A.; Kosev, V.I. Analysis of Character Association of Quantitative Traits in Lupinus Species. J. Agric. Sci. 2016, 8, 23. [CrossRef]

56. Clements, J.; Buirchell, B.; Cowling, W. Relationship between morphological variation and geographical origin or selection history in Lupinus pilosus. Plant Breed. 2006, 115, 16-22. [CrossRef]

57. Johnson, H.W.; Robinson, H.F.; Comstock, R.E. Estimates of Genetic and Environmental Variability in Soybeans. Agron. J. 1955, 47, 314. [CrossRef]

58. Hussain, Q.A.; Tariq, K.; Iftikhar, A.; Nazir, A.; Muhammad, A.; Muhammad, F.; Muhammad, U. Estimation of heritability and selection response for some yield traits in F3 populations of wheat. Int. J. Agric. Appl. Sci. 2017, 9, 6-13.

59. Girma, G.; Tesfaye, K.; Bekele, E. Inter-simple sequence repeat (ISSR) analysis of wild and cultivated rice species from Ethiopia. Afr. J. Biotechnol. 2010, 9, 5048-5059.

60. Hashimoto, Z.; Mori, N.; Kawamura, M.; Ishii, T.; Yoshida, S.; Ikegami, M.; Takumi, S.; Nakamura, C. Genetic diversity and phylogeny of Japanese sake-brewing rice as revealed by AFLP and nuclear and chloroplast SSR markers. Theor. Appl. Genet. 2004, 109, 1586-1596. [CrossRef]

61. Chirinos-Aria, M.C.; Jiménez, J.E. Transference of some microsatellite molecular markers from Fabaceae family to Andean Lupin (Lupinus mutabilis Sweet). Sci. Agropecu. 2015, 6, 51-58. [CrossRef]

62. Bussell, J.D.; Waycott, M.; Chappill, J.A. Arbitrarily amplified DNA markers as characters for phylogenetic inference. Perspect. Plant Ecol. Evol. Syst. 2005, 7, 3-26. [CrossRef]

63. Adhikari, S.; Saha, S.; Bandyopadhyay, T.K.; Ghosh, P. Efficiency of ISSR marker for characterization of Cymbopogon germplasms and their suitability in molecular barcoding. Plant Syst. Evol. 2014, 301, 439-450. [CrossRef]

64. Aykut Tonk, F.; Tosun, M.; Ilker, E.; Istipliler, D.; Tatar, O. Evaluation and comparison of ISSR and RAPD markers for assessment of genetic diversity in triticale genotypes. Bulg. J. Agric. Sci. 2014, 20, 1413-1420.

65. Grativol, C.; Lira-Medeiros, C.D.F.; Hemerly, A.S.; Ferreira, P.C.G. High efficiency and reliability of inter-simple sequence repeats (ISSR) markers for evaluation of genetic diversity in Brazilian cultivated Jatropha curcas L. accessions. Mol. Boil. Rep. 2010, 38, 4245-4256. [CrossRef] 
66. Hajiyeva, S.V.; Akparov, Z.I.; Hasanov, N.A.; Mustafayeva, Z.P.; Hajiyev, E.S.; Mammadov, A.T.; Izzatullayeva, V.I.; Babayeva, S.M.; Sharifova, S.S.; Mammadov, A.M.; et al. ISSR Analysis of Variability of Cultivated Form and Varieties of Pomegranate (Punica granatum L.) from Azerbaijan. Russ. J. Genet. 2018, 54, 188-197. [CrossRef]

67. Lamare, A.; Rao, S.R. Efficacy of RAPD, ISSR and DAMD markers in assessment of genetic variability and population structure of wild Musa acuminata colla. Physiol. Mol. Boil. Plants 2015, 21, 349-358. [CrossRef]

68. Chen, H.; Chen, H.; Hu, L.; Wang, L.; Wang, S.; Wang, M.L.; Cheng, X. Genetic diversity and a population structure analysis of accessions in the Chinese cowpea [Vigna unguiculata (L.) Walp.] germplasm collection. Crop J. 2017, 5, 363-372. [CrossRef]

69. Li, Z.; Liu, X.; Gituru, R.W.; Juntawong, N.; Zhou, M.; Chen, L. Genetic diversity and classification of Nelumbo germplasm of different origins by RAPD and ISSR analysis. Sci. Hortic. 2010, 125, 724-732. [CrossRef]

70. Naganowska, B.; Wolko, B.; Śliwińska, E.; Kaczmarek, Z. Nuclear DNA Content Variation and Species Relationships in the Genus Lupinus (Fabaceae). Ann. Bot. 2003, 92, 349-355. [CrossRef]

71. Rayburn, A.L.; Biradar, D.P.; Nelson, R.L.; McCloskey, R.; Yeater, K.M. Documenting Intraspecfic Genome Size Variation in Soybean. Crops Sci. 2004, 44, 261-264. [CrossRef]

72. Realini, M.F.; Poggio, L.; Cámara-Hernández, J.; González, G.E. Intra-specific variation in genome size in maize: Cytological and phenotypic correlates. AoB Plants 2015, 8, 138. [CrossRef]

73. Wang, W.; Kerstetter, R.A.; Michael, T.P. Evolution of Genome Size in Duckweeds (Lemnaceae). J. Bot. 2011, 2011, 1-9. [CrossRef]

74. Garrido-Ramos, M.A. Satellite DNA in Plants: More than Just Rubbish. Cytogenet. Genome Res. 2015, 146, 153-170. [CrossRef]

75. Petrov, D.A. Evolution of genome size: New approaches to an old problem. Trends Genet. 2001, 17, 23-28. [CrossRef]

76. Garrido-Ramos, M.A. Satellite DNA: An Evolving Topic. Genes 2017, 8, 230. [CrossRef]

77. Cullis, C.A. Mechanisms and Control of Rapid Genomic Changes in Flax. Ann. Bot. 2005, 95, $201-206$. [CrossRef]

78. Basak, S.; Sun, X.; Wang, G.; Yang, Y. Genome Size Unaffected by Variation in Morphological Traits, Temperature, and Precipitation in Turnip. Appl. Sci. 2019, 9, 253. [CrossRef]

79. Beaulieu, J.M.; Moles, A.T.; Leitch, I.J.; Bennett, M.D.; Dickie, J.B.; Knight, C.A. Correlated evolution of genome size and seed mass. New Phytol. 2007, 173, 422-437. [CrossRef] 